Prepared for the U.S. Department of Energy

under Contract DE-AC05-76RL01830

\title{
Demonstration of LED Retrofit Lamps at the Jordan Schnitzer Museum of Art
}

N Miller

September 2011

\section{Pacific Northwest}

NATIONAL LABORATORY

Proudly Operated by Battelle Since 1965 


\title{
DISCLAIMER
}

This report was prepared as an account of work sponsored by an agency of the United States Government. Neither the United States Government nor any agency thereof, nor Battelle Memorial Institute, nor any of their employees, makes any warranty, express or implied, or assumes any legal liability or responsibility for the accuracy, completeness, or usefulness of any information, apparatus, product, or process disclosed, or represents that its use would not infringe privately owned rights. Reference herein to any specific commercial product, process, or service by trade name, trademark, manufacturer, or otherwise does not necessarily constitute or imply its endorsement, recommendation, or favoring by the United States Government or any agency thereof, or Battelle Memorial Institute. The views and opinions of authors expressed herein do not necessarily state or reflect those of the United States Government or any agency thereof.

\author{
PACIFIC NORTHWEST NATIONAL LABORATORY \\ operated by \\ BATTELLE \\ for the \\ UNITED STATES DEPARTMENT OF ENERGY \\ under Contract DE-AC05-76RL01830
}

Printed in the United States of America
Available to DOE and DOE contractors from the Office of Scientific and Technical Information,
P.O. Box 62, Oak Ridge, TN 37831-0062;
ph: (865) 576-8401
fax: $(865) 576-5728$
email: reports@adonis.osti.gov

\footnotetext{
Available to the public from the National Technical Information Service, U.S. Department of Commerce, 5285 Port Royal Rd., Springfield, VA 22161 ph: (800) 553-6847 fax: $(703) 605-6900$ email: orders@ntis.fedworld.gov online ordering: http://www.ntis.gov/ordering.htm
}

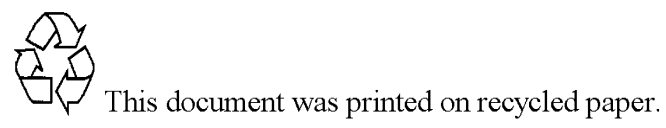

(9/2003) 


\section{Demonstration of LED Retrofit Lamps in the Jordan Schnitzer Museum of Art}

Final Report prepared in support of the U.S. DOE Solid-State Lighting Technology Demonstration GATEWAY Program

Study Participants:

Pacific Northwest National Laboratory

U.S. Department of Energy

Bonneville Power Administration

Eugene Water and Electricity Board

N Miller

September 2011

Prepared for

the U.S. Department of Energy

under Contract DE-AC05-76RL01830

Pacific Northwest National Laboratory

Richland, Washington 99352 



\section{Preface}

This document is a report of observations and results obtained from a lighting demonstration project conducted under the U.S. Department of Energy (DOE) GATEWAY Demonstration Program. The program supports demonstrations of high-performance solid-state lighting (SSL) products in order to develop empirical data and experience with in-the-field applications of this advanced lighting technology. The DOE GATEWAY Demonstration Program focuses on providing a source of independent, third-party data for use in decision-making by lighting users and professionals; this data should be considered in combination with other information relevant to the particular site and application under examination. Each GATEWAY Demonstration compares SSL products against the incumbent technologies used in that location. Depending on available information and circumstances, the SSL product may also be compared to alternate lighting technologies. Though products demonstrated in the GATEWAY program have been prescreened for performance, DOE does not endorse any commercial product or in any way guarantee that users will achieve the same results through use of these products.

\section{Acknowledgements}

Kurt Neugebauer, Associate Director Administration and Exhibitions at the Jordan Schnitzer Museum of Art, provided access to this exhibit and design process, provided access to museum staff and visitors for the survey responses, and donated the use of the exhibit photographs. Doug Oppedal, Senior Lighting Specialist at the Evergreen Consulting Group, collected measurements and surveys. Veronika Lausmann Brenner created the lighting plan and performed initial calculations on the expected performance of several LED lamps. Michael Myer and Bruce Kinzey of Pacific Northwest National Laboratory (PNNL) did the initial footwork for this demonstration, and Eric Richman of PNNL contributed supportive editing. Bonneville Power Administration and the Eugene Water and Electricity Board provided sample lamps and essential support for this demonstration. 



\section{Executive Summary}

The Jordan Schnitzer Museum of Art in Eugene, Oregon, houses a remarkable permanent collection of Asian art and antiquities, modern art, and sculpture, and also hosts traveling exhibitions. In the winter and spring of 2011, a series of digital photographs by artist Chris Jordan, titled "Running the Numbers," was exhibited in the Coeta and Donald Barker Special Exhibitions Gallery. These works graphically illustrate waste (energy, money, health, consumer objects, etc.) in contemporary culture. The Bonneville Power Administration and the Eugene Water and Electricity Board provided a set of Cree 12W lightemitting diode (LED) PAR38 replacement lamps (Cree LRP38) for the museum to test for accent lighting in lieu of their standard Sylvania 90W PAR38 130V Narrow Flood lamps (which draw 78.9W at 120V). At the same time, the museum tested LED replacement lamps from three other manufacturers, and chose the Cree lamp as the most versatile and most appropriate color product for this exhibit. The lamps were installed for the opening of the show in January 2011. This report describes the process for the demonstration, the energy and economic results, and results of a survey of the museum staff and gallery visitors on four similar clusters of art lighted separately by four PAR38 lamps.

The gallery was lighted for dramatic effect, with vertical illuminances on the artwork as high as 198 lux (18.4 footcandles [fc]) and as low as 11 lux (1.0 fc) between the canvases. Visitors are accustomed to the low light levels that are common for museums where conservation of the art is a primary goal.

A total of 54 track heads lamped with the LED lamps would use $1403 \mathrm{kWh}$ per year compared to $9851 \mathrm{kWh}$ for the estimated number of halogen lamps required for the same lighting effect. At the melded electrical rate of $\$ 0.06$ per $\mathrm{kWh}$, this translates to a savings of $\$ 506.84$ per year for the gallery. Using only $14 \%$ of the energy and having a life 10 times longer than the halogen lamp, the LED system has a present value life-cycle cost of $\$ 12,124$, compared to $\$ 16,670$ for the halogen system. Simple payback occurs in year 9 of operation. At $\$ 0.10$ per $\mathrm{kWh}$, simple payback drops to less than 6 years; at $\$ 0.15$ per $\mathrm{kWh}$, payback occurs in less than 4 years. Payback rates will improve further as the industry works to reduce the price of LED replacement lamps. The Cree PAR38 lamps cost \$108 each at the time of this GATEWAY study, compared to $\$ 5.42$ per lamp for the standard halogen lamp.

To get feedback on the appearance and acceptability of the LED PAR38 replacement lamps, a sideby-side comparison was done in the nearby Gordon Gilkey Study Center Gallery. Four clusters of similar art from the museum's archives were mounted on a single gray wall. Each cluster included an oil painting with a wide color palette, a black-and-white photographic print, and a color-checker card. Each cluster was illuminated with one of four different lamps (designated lamps A through D), concealed from view inside cylinder-shaped track heads. There were three LED lamps and one halogen lamp, all with color temperatures ranging between $2638 \mathrm{~K}$ and 2821K. Museum staff and visitors were invited to observe the four clusters and complete a questionnaire. No lenses, louvers, or screens were used to control the light output or distribution, and artwork illuminances ranged from 200 to 330 lux (19 to 31 fc).

Museum staff preferred lamp C (the same Cree LED replacement lamp selected for lighting the Barker Gallery) for smoothness of light pattern, appropriate warmth/coolness of light for the art, color rendering, visual clarity, suitability of the lighting for the color painting, and suitability for the black-andwhite print. Visitors preferred a different LED replacement lamp, lamp B, but found the halogen lamp equally appropriate for smoothness of the light pattern. Interestingly, neither the public nor the museum staff clearly preferred the halogen option (lamp D). Observers appreciated how the LED lamps improved 
ability to see blue colors. Preferences did not correspond to color rendering index (CRI) values, since both preferred lamps had CRI values lower than the halogen lamp (lamp C, 93 CRI; lamp B, 85 CRI; lamp D, 99 CRI).

This demonstration showed that carefully chosen LED replacement lamps can provide an equivalent or even preferred appearance of art in comparison to halogen lamps, while using only a fraction (14\% in this case) of the latter's energy use. Both the artist and the museum staff, who are expected to have high standards for visibility and color rendering of artistic details, had high praise for this technology and are looking forward to testing it on future exhibits. 


\section{Contents}

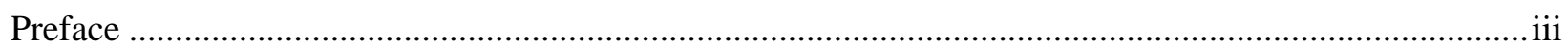

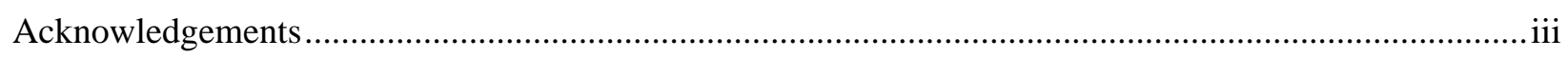

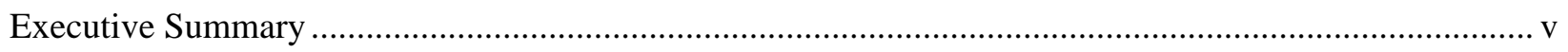

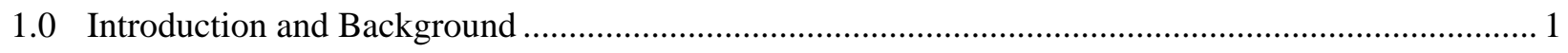

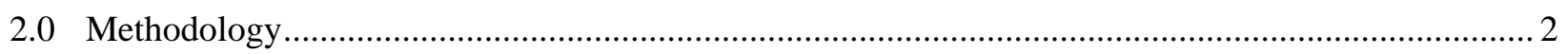

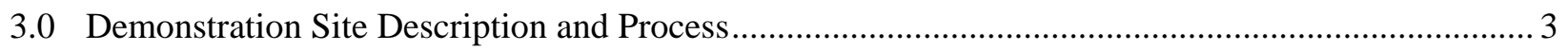

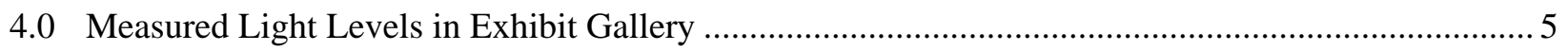

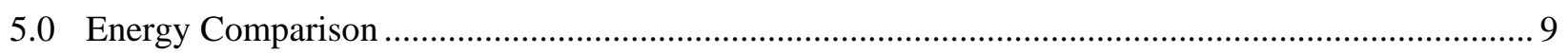

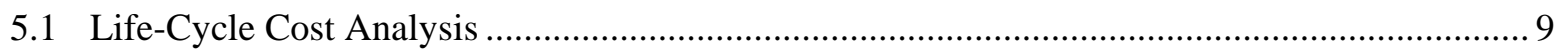

5.2 Payback Horizons and Economic Feasibility ....................................................................... 10

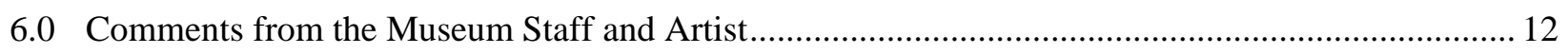

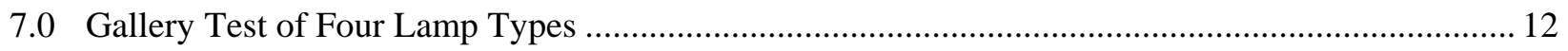

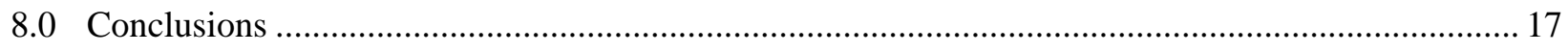

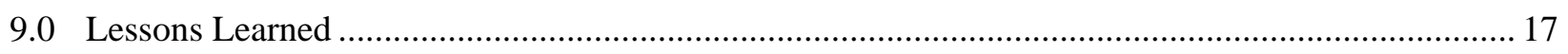

Appendix A : University of Oregon Jordan Schnitzer Museum of Art - Barker Gallery Input Data for Life-Cycle Cost Analysis ......................................................................................... A.1

Appendix B : Summary Life-Cycle Cost Calculations ...........................................................................

Appendix C : Comparative Analysis of Life-Cycle Cost........................................................................1

Appendix D : Questionnaire on Lighting Mockup in Gilkey Gallery ................................................ D.1

\section{Figures}

Figure 1. Jordan Schnitzer Museum of Art at University of Oregon. (Photo courtesy of JSMA)............... 2

Figure 2. Mockup of four LED lamp types (left wall) in the Barker Gallery. The Cree PAR38

("LRP38") lamp is on the far left, nearest the viewer. The incumbent halogen lamp is projected on the far wall. There were no screens, louvers, or lenses in place to modify the projected beams in the track heads for this test. Notice the difference in color and beam edge among the different lamps.

Figure 3. Plan of Barker Gallery at JSMA, showing tracks, track heads, approximate direction of aiming, and location of Chris Jordan artwork. Gallery dimensions are 132 feet by 29 feet 11 inches. (Drawing by Veronika Lausmann Brenner.)

Figure 4. "Light Bulbs, 2008” by Chris Jordan. This 72 by 96 inch piece “depicts 320,000 lightbulbs, equal to the number of kilowatt hours of electricity wasted in the United States every minute from inefficient residential electricity usage (inefficient wiring, computers in sleep mode, etc.).” (Quoted from caption at www.chrisjordan.com.)

Figure 5. JSMA's lighting technician aiming the track lights for "Light Bulbs, 2008” by Chris Jordan.

Figure 6. Photo of the gallery with "Running the Numbers" exhibit. All track heads are lamped with Cree “LRP38” lamps (12W LED PAR38, 2700K, 20 beam). (Photo courtesy of JSMA.). 
Figure 7. Measured vertical illuminances in lux (footcandles) on "Light Bulbs, 2008."

Figure 8. Exhibit featuring “Cans Seurat, 2011” by Chris Jordan. “This depicts 400,000 bottle caps, equal to the average number of plastic bottles consumed in the United States every minute.” (Quote from www.chrisjordan.com; photo courtesy of JSMA.).

Figure 9. Vertical illuminance in lux (footcandles), measured on Cans Seurat, 2011............................. 9

Figure 10. Gilkey Gallery with the four clusters of artwork arrayed along one wall. Each cluster was lighted with a different PAR38 lamp, lamp A (on left) through to lamp D (on far right).

(Photo by PNNL.)

Figure 11. Cluster of artwork lighted by lamp A, as viewed for questionnaire. (Photo by PNNL.)......... 15

Figure 12. Average responses on questionnaire from museum staff and exhibition artist, and visitors. Yellow indicates preferred lamp for each group.

\section{Tables}

Table 1. Illuminances measured in Barker Gallery during "Running the Numbers” exhibit.

Values were measured using a new Extech LT-300 light meter.

Table 2. JSMA Barker Gallery accent lighting life-cycle cost analysis (including relamping labor) - input data and summary.

Table 3. Comparison of four lamps used in side-by-side test of PAR38 display lamps in Gilkey Gallery. Center beam candlepower, beam angle, lumens, watts, CCT, and CRI were taken from independent photometric tests performed for this GATEWAY study for lamps C and D. Data for A and B were derived from manufacturer's data. Polar plot was approximated for lamp A 


\subsection{Introduction and Background}

The Jordan Schnitzer Museum of Art (JSMA) at the University of Oregon in Eugene houses a remarkable range of art, including an extensive collection of Asian fine and decorative art, and contemporary painting, prints, mixed media work, and sculpture. The museum also hosts temporary exhibitions and during this GATEWAY demonstration project featured "Chris Jordan: Running the Numbers,” a collection of digitally designed photographic prints by Seattle-based artist Chris Jordan. The works in this exhibition graphically communicate the scale of mass consumption and waste in contemporary society, in a consciousness-raising and amusing way. This report describes the process and results of a demonstration of solid-state lighting technology in the JSMA.

The Coeta and Donald Barker Special Exhibitions Gallery of the JSMA conventionally used halogen 90W PAR38, $25^{\circ}$ beam, $130 \mathrm{~V}$ lamps for both accent lighting and wallwashing. (Operated at 120V, the lamp draws approximately $79 \mathrm{~W}$ and emits $24 \%$ less than its full rated output, but its average life is doubled to 5000 hours. The $130 \mathrm{~V}$ lamps employ a longer tungsten filament than $120 \mathrm{~V}$ lamps-a common technique for extending the lifetime of halogen products.) The museum's standard track heads accommodate glass UV filters, glass linear and spread lenses, louvers, screens, and other media to control the spread and intensity of light from the standard halogen lamps. The museum was offered a number of trial light-emitting diode (LED) replacement lamps by its local electric utility, Eugene Water and Electricity Board (EWEB), funded by the Bonneville Power Administration (BPA). After preliminary testing of three manufacturers' lamps, the museum staff decided to use the Cree $12 \mathrm{~W}$ PAR38, $20^{\circ}$ beam, 120V LED lamps for this exhibit. The artist agreed that energy-efficient LED products were especially appropriate for illuminating his work since they would exemplify a means to reduce waste. The exhibit ran from January through April 2011.

Another reason that the Chris Jordan exhibit was ideal for testing the LED lamps is that the graphical design, developed with computer graphics software, is printed on canvas using a special large format printer. Because it is printed, the work can be reproduced. This was important to help allay uncertainty at the start of this project regarding whether the LED products might introduce greater damage potential for unique art objects. ${ }^{1}$

To gather feedback on the LED lighting from both its staff and exhibit visitors, the museum mocked up four accent lighting alternatives in the Gordon Gilkey Study Center Gallery—a smaller gallery near the Chris Jordan exhibit. Displayed on one wall of the Gilkey Gallery were four clusters of objects: an oil painting with colors that spanned the color spectrum, a black-and-white photographic print, and a Gretag-MacBeth color checker chart. (For more details and a photo of the mockup, see section 7.) The art came from the museum's collection, and was selected to have similar subjects and characteristics. Each cluster was illuminated using a different PAR38 lamp type: three clusters were illuminated by LED replacement lamps and one was illuminated by the museum's standard 90W 130V halogen display lamp. Staff and visitors were invited to view the displays and to complete a questionnaire about them.

The GATEWAY Project objectives included demonstrating the lighting quality and documenting the performance of the new LED replacement lamps for visitors and museum staff. BPA and EWEB are

\footnotetext{
${ }^{1}$ Ongoing research results from the Getty Conservation Institute are suggesting no worse damage from warm-color white-light LEDs than from halogen lamps, given equivalent lux-hours of exposure on the specific materials studied. Look for a future GATEWAY report containing additional details.
} 
interested in demonstrating the energy and cost savings potential of this new technology, and partnered with Pacific Northwest National Laboratory (PNNL) and the U.S. Department of Energy (DOE) to document the performance and the acceptance of these lamps for critical viewing applications.

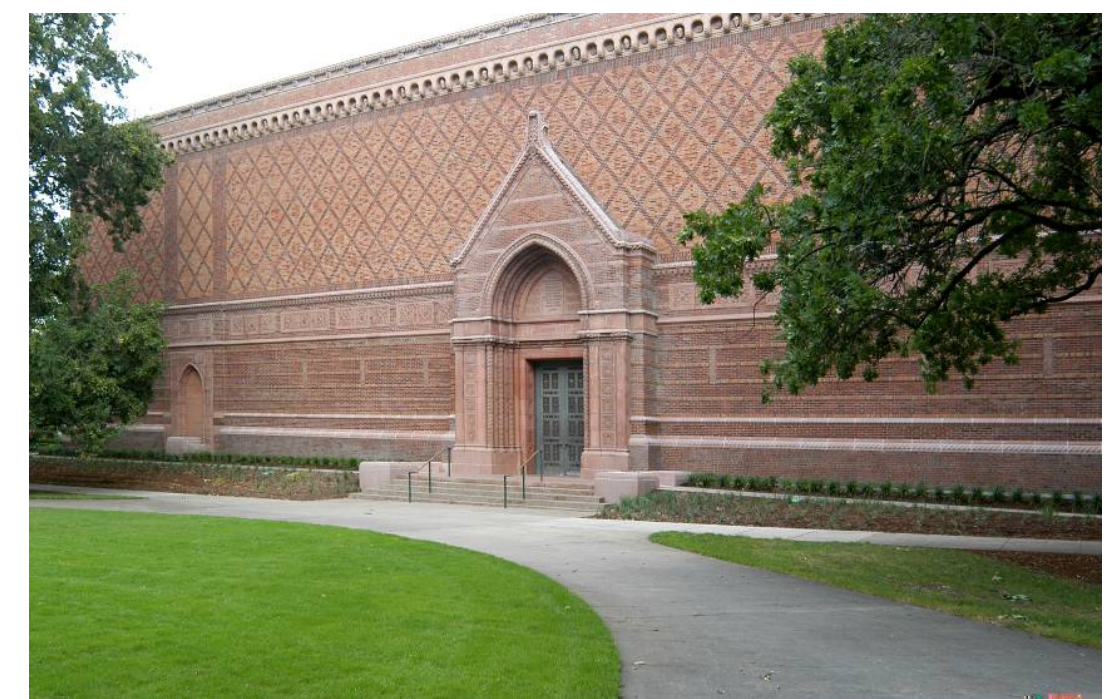

Figure 1. Jordan Schnitzer Museum of Art at University of Oregon. (Photo courtesy of JSMA.)

\subsection{Methodology}

The museum, utility partners, and PNNL agreed on the following steps for this LED demonstration:

- Work with the JSMA to locate samples of LED PAR38 lamp replacements from three manufacturers. Mock them up in the Barker Gallery to choose best lamp for the exhibit. Selected LED lamps were donated by BPA and EWEB.

- Lamp, install, and aim track luminaires for the exhibit in the Barker Gallery (JSMA staff).

- Send two representative lamps of the incumbent halogen and the Cree LRP38 LED replacement lamps to an independent photometric laboratory for sphere testing for color, light output, and power metrics. All lamps were new.

- Mock up four clusters of similar art in the smaller Gilkey Gallery, each lighted by a different PAR38 lamp. LED replacement lamps by Sylvania, Philips, and Cree illuminated three of the clusters, with the incumbent halogen lamp illuminating the fourth. Develop a questionnaire for visitors, museum staff, and the artist and collect data for one month.

- Document the layout of lighting for the Chris Jordan exhibit in the Barker Gallery with scaled drawings and photographs. Calculate energy use in gallery and measure illuminances.

- Conduct interviews with the artist and museum staff for reactions to the LED lamping in both the Barker Gallery (the formal exhibit) and the Gilkey Gallery (test of four lamps and art clusters).

- Collect information on hours of operation for the lighting system in the Barker Gallery.

- Perform a life-cycle cost study and document the relative performance of the lamps in a GATEWAY report. 


\subsection{Demonstration Site Description and Process}

A museum exhibit gallery is a difficult environment for testing new lamp types because the color and distribution of light may affect the appearance of the artwork, making it difficult for the viewer to fully appreciate the art. Consequently, museum directors, curators, designers, and visitors are critical audiences. BPA procured a set of PAR38 LED integral replacement lamps for distribution to different types of sites to demonstrate the lighting characteristics and energy savings they offer. The JSMA is progressive about investigating energy-efficiency measures, and offered to try the lamps and provide feedback.

In January 2011, before the Chris Jordan artwork had been installed, the museum lighting designers and staff tested four different LED PAR38 replacement lamps. Lamps were installed in the gallery track heads and aimed side-by-side against the gallery's white wall (see Figure 2). The apparent beam diameter, intensity, and color differed considerably, even though the lamps had similar specifications. The Cree PAR38 LED $20^{\circ}$ beam replacement lamp was preferred for this exhibit and seemed most consistent in color from lamp to lamp. The exhibit designer proceeded to install this lamp and focus the track heads on artwork, display pylons, signage, walkways, and seating once the exhibit was in place.

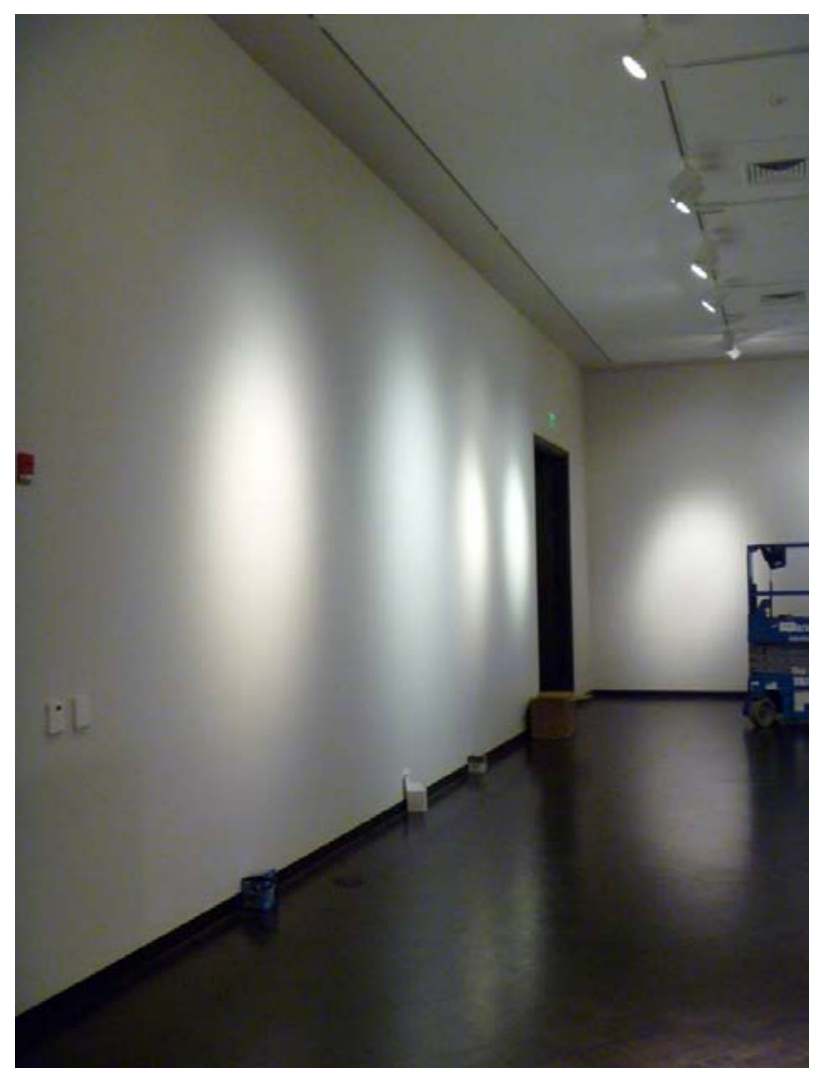

Figure 2. Mockup of four LED lamp types (left wall) in the Barker Gallery. The Cree PAR38 (“LRP38”) lamp is on the far left, nearest the viewer. The incumbent halogen lamp is projected on the far wall. There were no screens, louvers, or lenses in place to modify the projected beams in the track heads for this test. Notice the difference in color and beam edge among the different lamps.

The maximum target vertical illuminance on the artwork at JSMA is 269 lux (25 footcandles [fc]), but the illuminance varies according to the specific artwork and gallery. The lighting designer uses a 
combination of light screens, spread lenses, and cross baffles to reduce the light output and shape the beam in order to achieve the best visual effect on the artwork. The lighting designer for the Chris Jordan exhibit commented that, for the most part, the LED lamps produced the desired intensity and light distribution, and could replace a halogen lamp one-for-one. However, because the lamp was slightly narrower than the standard $25^{\circ}$ halogen lamp used elsewhere in the museum, he would use comparatively more of the LED lamps for the larger pieces of the exhibit. Figure 3 shows the Barker Gallery plan, with artwork, track head counts, and rough aiming of the lighting illustrated. Figure 4 is a picture of one of the Chris Jordan art pieces, and Figure 5 shows the JSMA lighting technician focusing the accent lighting on this piece.

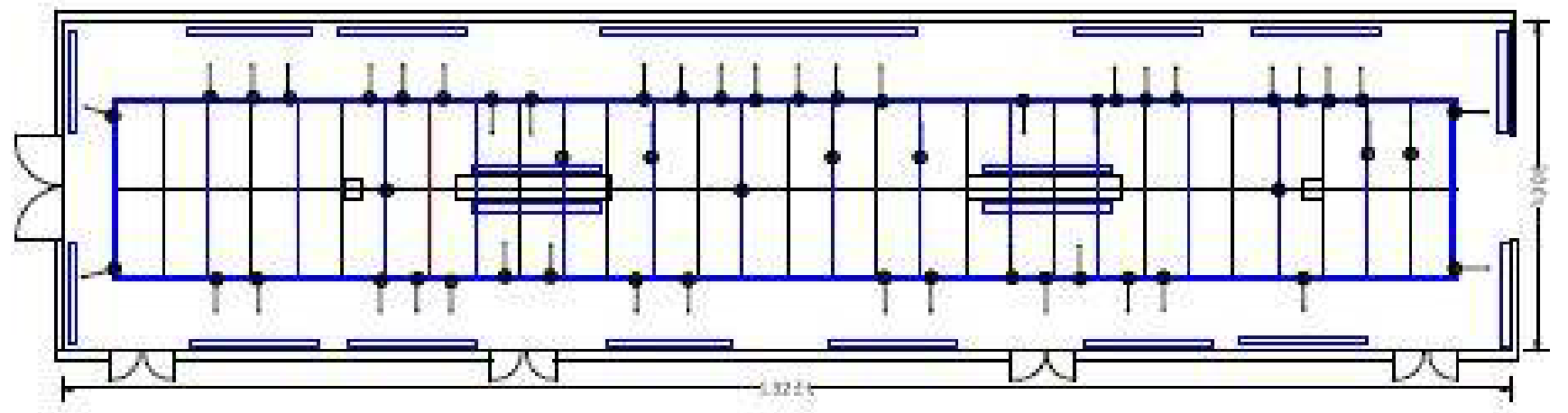

Figure 3. Plan of Barker Gallery at JSMA, showing tracks, track heads, approximate direction of aiming, and location of Chris Jordan artwork. Gallery dimensions are 132 feet by 29 feet 11 inches. (Drawing by Veronika Lausmann-Brenner.)

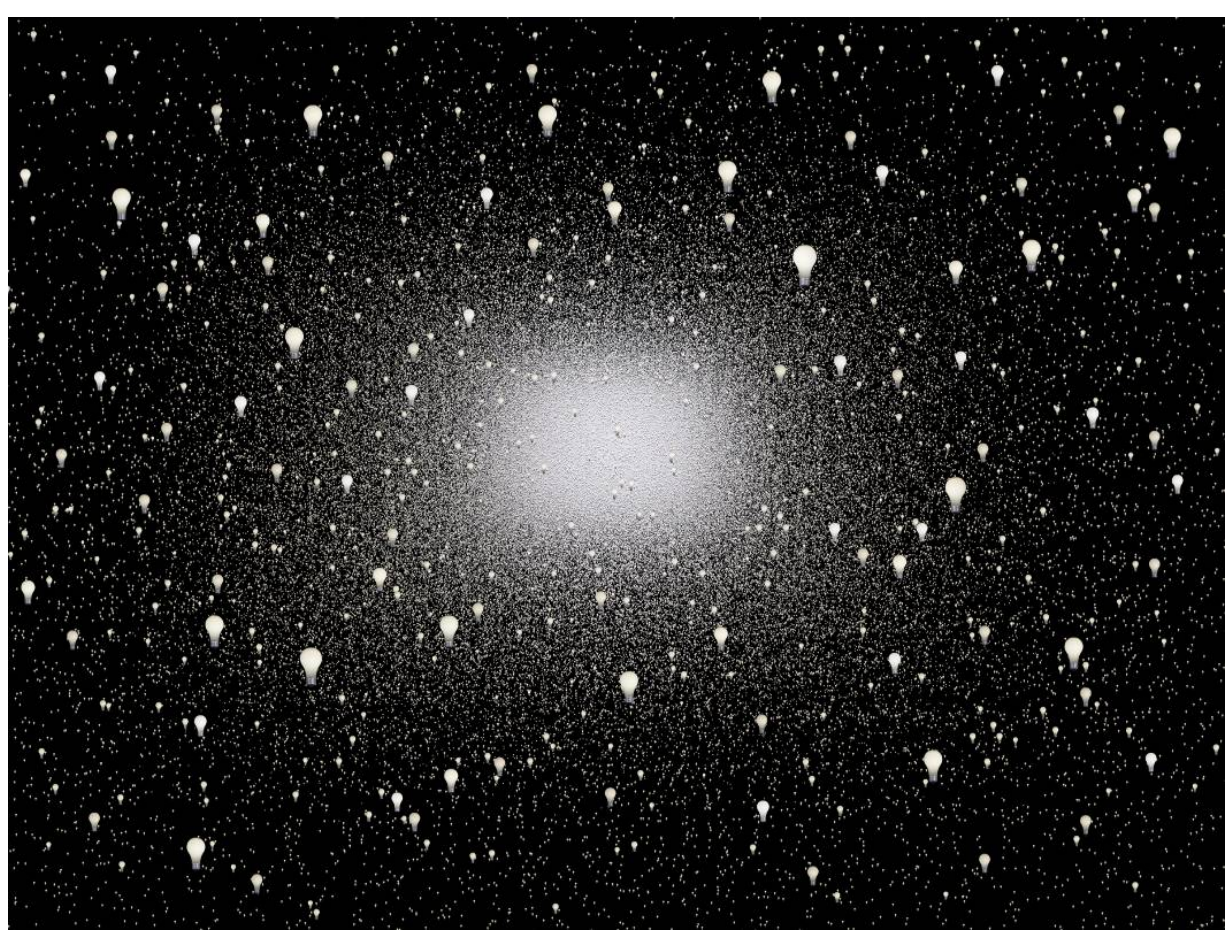

Figure 4. "Light Bulbs, 2008” by Chris Jordan. This 72 by 96 inch piece “depicts 320,000 lightbulbs, equal to the number of kilowatt hours of electricity wasted in the United States every minute from inefficient residential electricity usage (inefficient wiring, computers in sleep mode, etc.).” (Quoted from www.chrisjordan.com.) 


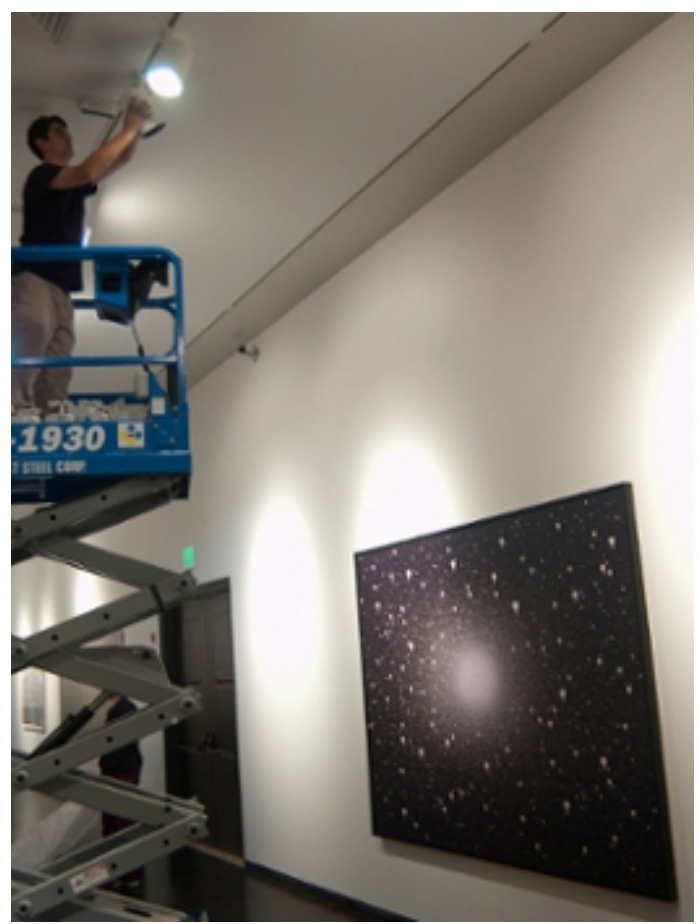

Figure 5. JSMA’s lighting technician aiming the track lights for “Light Bulbs, 2008.”

\subsection{Measured Light Levels in Exhibit Gallery}

The Barker Gallery was lighted with 54 track heads, all lamped with the LED replacement lamps. To illuminate the large works evenly, the lighting designer installed glass linear spread lenses in the accessory holders in front of each lamp. (Linear spread lenses use parallel prisms to optically convert a round light beam into an elongated beam.) Figure 6 and Figure 8 are views of the completed gallery installation. 


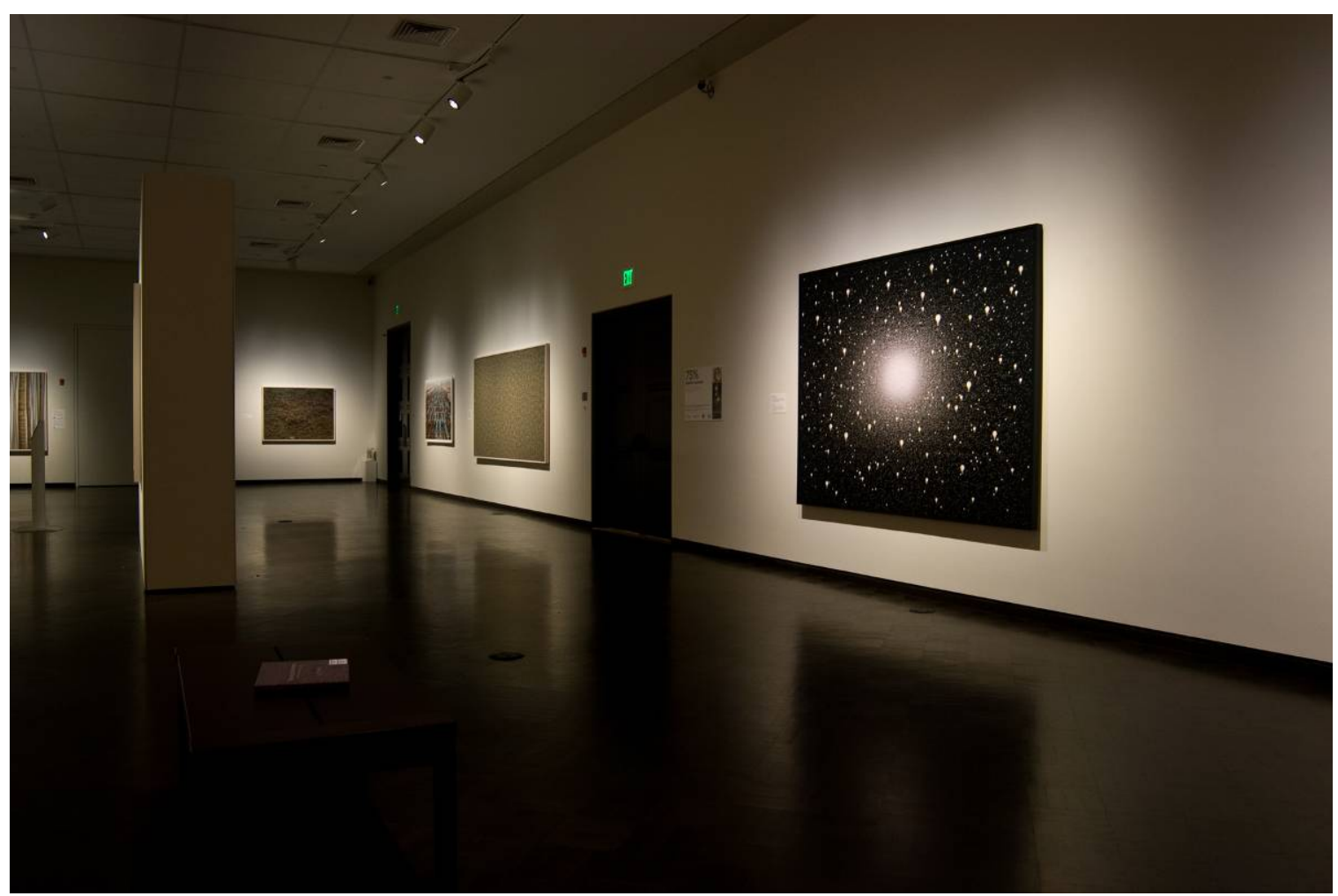

Figure 6. Photo of the gallery with "Running the Numbers" exhibit. All track heads are lamped with Cree “LRP38” lamps (12W LED PAR38, 2700K, 20 beam). (Photo courtesy of JSMA.)

Light levels in the Barker Gallery were the low values typical of museum galleries. The range of illuminances is shown in Table 1. Because visitors are accustomed to such low levels, the artwork stands out even when lighted with only 39 to 198 vertical lux (3.6 to 18.4 vertical footcandles). 
Table 1. Illuminances measured in Barker Gallery during "Running the Numbers" exhibit. Values were measured using a new Extech LT-300 light meter.

\begin{tabular}{lcc}
\hline & Minimum illuminance & Maximum illuminance \\
\hline Floor illuminance & 11 lux (1.0 fc) & 32 lux (3.0 fc) \\
Vertical illuminance on artwork & 39 lux (3.6 fc) & 198 lux (18.4 fc) \\
$\begin{array}{l}\text { Vertical illuminance on walls between artwork } \\
\text { locations (measured } 5 \mathrm{ft} \text { above floor) }\end{array}$ & $11 \operatorname{lux}(1.0 \mathrm{fc})$ & $38 \mathrm{lux}(3.5 \mathrm{fc})$ \\
\hline
\end{tabular}

Figure 7 illustrates the vertical illuminances measured on the "Light Bulbs, 2008" work, and Figure 9 the vertical illuminances on "Cans Seurat, 2011.”
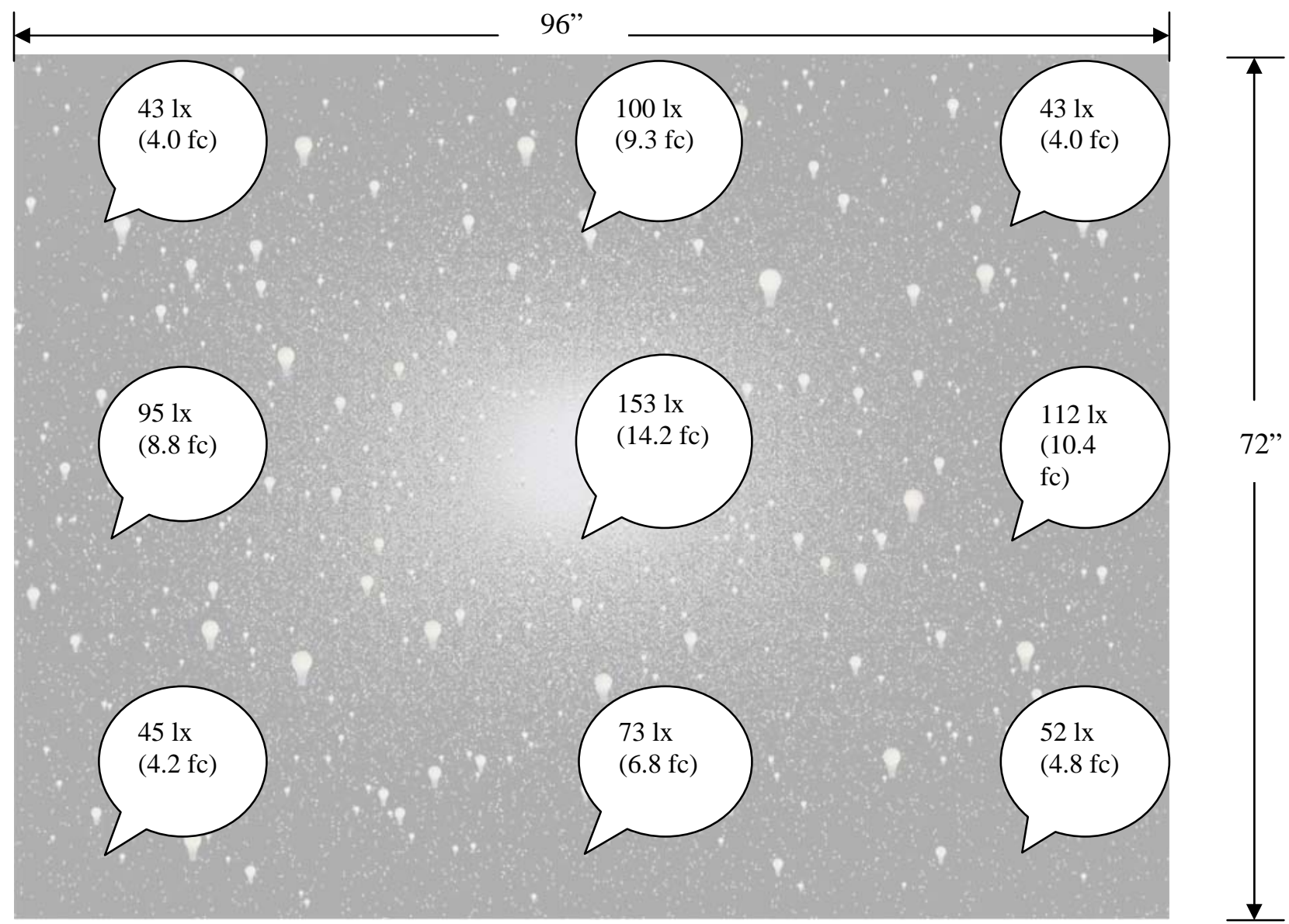

Figure 7. Measured vertical illuminances in lux (footcandles) on “Light Bulbs, 2008.” 


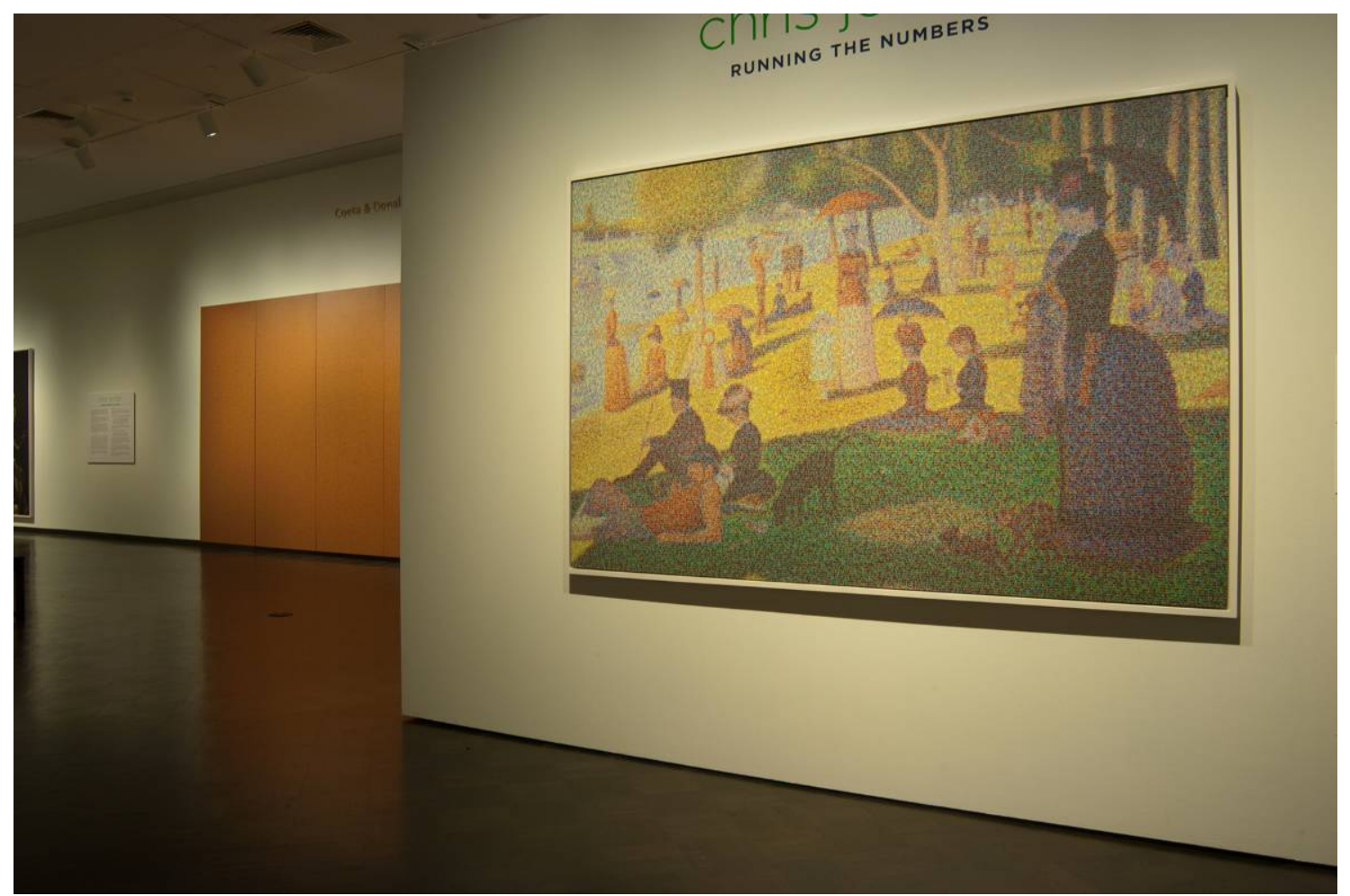

Figure 8. Exhibit featuring “Cans Seurat, 2011” by Chris Jordan. “This depicts 400,000 bottle caps, equal to the average number of plastic bottles consumed in the United States every minute." (Quote from www.chrisjordan.com; photo courtesy of JSMA.) 


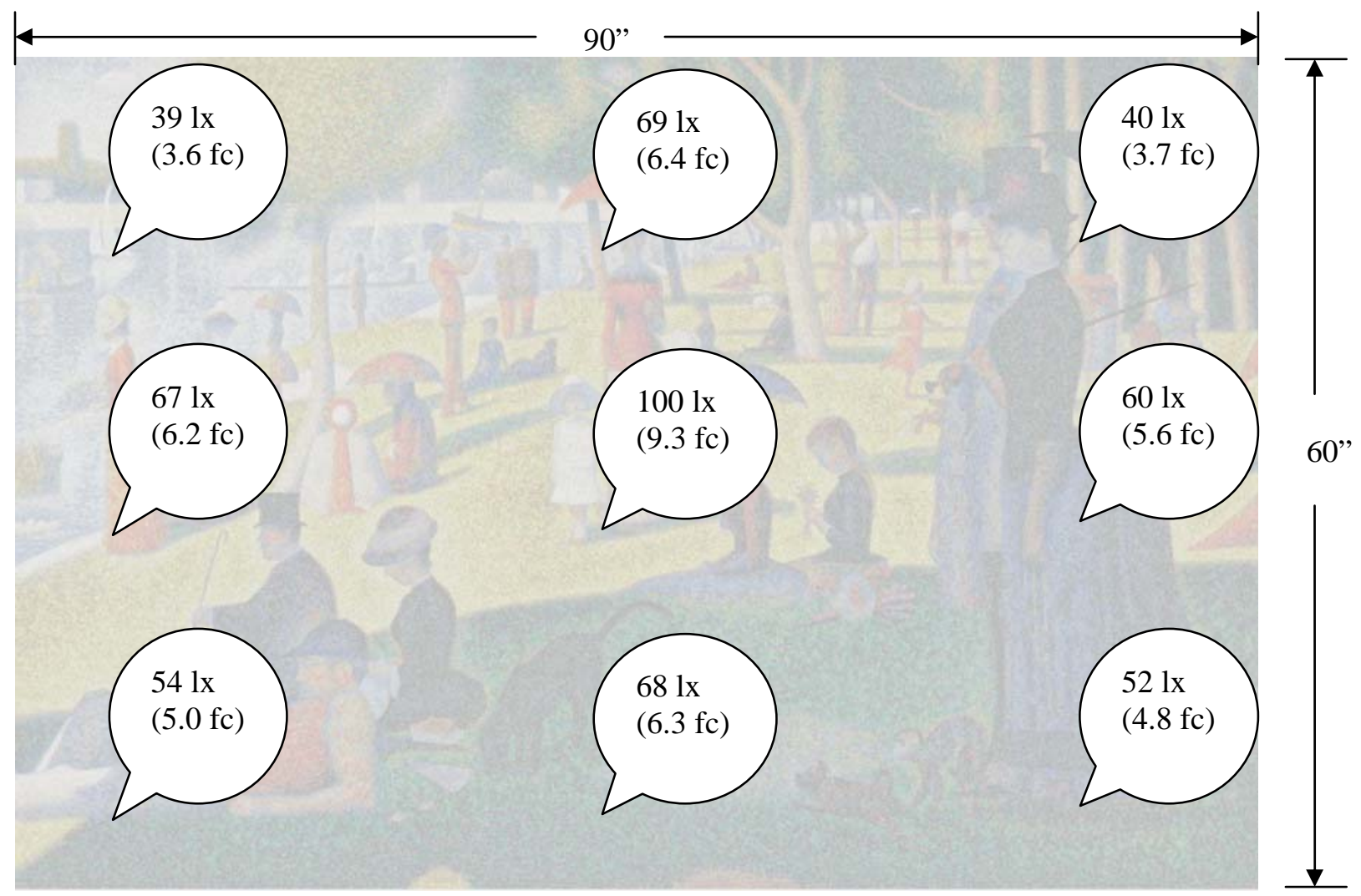

Figure 9. Vertical illuminance in lux (footcandles), measured on Cans Seurat, 2011.

\subsection{Energy Comparison}

The LED replacement lamp lighting system with 54 track heads uses $1403.44 \mathrm{kWh}$ per year, compared to $9850.82 \mathrm{kWh}$ for the comparable halogen lighting system with 49 track heads. (GATEWAY assumed that because the halogen lamp has a larger beam angle and higher lumen output, $10 \%$ fewer halogen lamps would be needed for a comparable lighting effect.) At \$0.06 per kWh, this gallery’s lighting costs the University of Oregon $\$ 591.05$ per year using their standard halogen lamps, compared with only $\$ 84.21$ using the LEDs. Table 2 shows the corresponding reductions in annual emissions based on the electrical generation fuel mix for Oregon.

\subsection{Life-Cycle Cost Analysis}

The higher upfront costs of LED retrofit lamps are often offset by reduced electricity and maintenance costs over the long life of the LED lamps. The LED integral replacement lamps used in this retrofit project are on automatic control circuits, operated 49 hours per week, 52 weeks per year for a total of 2548 hours per year. The LED PAR38 lamps have a claimed useful $\left(\mathrm{L}_{70}\right)$ life of 50,000 hours, or about 20 years at this usage rate. The incumbent halogen lamp has an expected average life of 5000 hours when operated at $120 \mathrm{~V}$ (the point at which $50 \%$ of the lamps are expected to have failed), or about 2 years.

This economic analysis uses the National Institute of Standards and Technology's Building LifeCycle Cost (BLCC) software, ${ }^{2}$ which calculates the life-cycle costs for energy conservation projects. The

\footnotetext{
${ }^{2}$ Available online at http://www1.eere.energy.gov/femp/information/download_blcc.html.
} 
BLCC software was used to model the present value life-cycle cost of the (54) Cree 12W PAR38 LED lamps in comparison to the life-cycle costs had the museum's standard halogen lamps been installed. Recognizing that the LED lamps have a narrower beam angle and fewer emitted lumens, GATEWAY assumed that $10 \%$ fewer lamps would be required if the conventional lamp were used, so the comparison was made to (49) PAR38 halogen lamps. Both the halogen and LED scenarios are based on a 20-year analysis of each system's respective costs. This retrofit project is evaluated in terms of annualized spotrelamping costs (including labor at \$15 per lamp) and projected 20-year energy costs, taking into account projected real fluctuations in energy prices. Full details can be found in Appendices A through C.

In the United States, commercial electricity prices vary greatly from state to state and region to region. As a reference point, the DOE Energy Information Administration publishes the Average Retail Price of Electricity to Ultimate Customers by End-Use Sector by State. ${ }^{3}$ The national average retail price of electricity to ultimate commercial customers in April 2011 was approximately $\$ 0.10 / \mathrm{kWh}$, and commercial electricity prices ranged from a high of $\$ 0.284 / \mathrm{kWh}$ in the state of Hawaii, to a low of $\$ 0.066 / \mathrm{kWh}$ in Utah. The melded retail rate that the University of Oregon pays the local utility is below the national average at $\$ 0.06 / \mathrm{kWh}$. In general, LEDs are more likely to be economically viable in places where electricity costs are high enough that the energy savings they generate contribute significantly to paying back the high initial cost of LED products.

BLCC comparisons are based on "contractor-level” commercial lamp prices as quoted by a Portland electrical distributor, and confirmed by an online search of comparable prices. The Cree PAR38 LED lamps cost \$108 each at the time of this study, replacing halogen PAR38 lamps that cost \$5.42 each. No labor was included in the initial installation cost of the BLCC model because labor was identical for both lamp types. It was assumed that all lamps would be spot-relamped when one failed.

JSMA’s annualized halogen PAR38 lamp replacement cost is \$135.34 per year, including labor, while the LED PAR38 lamp annual replacement cost is \$297.20 (see Appendix A). While the LED lamps are not expected to require any maintenance or to fail during the 20 years of life-cycle analysis, to build a conservative scenario, GATEWAY assumed an annual lamp replacement value of

$$
\text { (54 or } 49 \text { lamps per gallery } \times \text { cost per lamp } \times 2548 \text { hours operation per year) }
$$

Rated lamp life

\subsection{Payback Horizons and Economic Feasibility}

Table 2 summarizes the input data and life-cycle-cost analysis for the incumbent halogen lamps and the replacement LED lamps.

\footnotetext{
${ }^{3}$ Available online at http://www.eia.gov/cneaf/electricity/epm/chap5.pdf .
} 
Table 2. JSMA Barker Gallery accent lighting life-cycle cost analysis (including relamping labor) - input data and summary.

\begin{tabular}{|c|c|c|}
\hline & $\begin{array}{c}\text { (49) Incumbent Sylvania } \\
90 \mathrm{~W} \text { Halogen PAR38 } 25^{\circ} \\
\text { Beam, 130V, Operated at } \\
\text { 120V }\end{array}$ & $\begin{array}{l}\text { (54) Cree “LRP38” 12W } \\
\text { PAR38, 20 Beam LED } \\
\text { Replacement }\end{array}$ \\
\hline Initial Capital Costs for All Components & $\$ 265.58$ & $\$ 5832$ \\
\hline Average Annual Electrical Energy Usage & $9850.82 \mathrm{kWh}$ & $1403.44 \mathrm{kWh}$ \\
\hline Average Electricity Cost per kWh & $\$ 0.06$ & $\$ 0.06$ \\
\hline First Year Energy Consumption Cost & $\$ 591.05$ & $\$ 84.21$ \\
\hline Study Period & 20 years & 20 years \\
\hline Discount Rate & $3.0 \%$ & $3.0 \%$ \\
\hline Discounting Convention & End-of-year & End-of-year \\
\hline $\begin{array}{l}\text { Present Value (PV), Energy Consumption } \\
\text { Costs }\end{array}$ & $\$ 8817$ & $\$ 1256$ \\
\hline Annual Value, Energy Consumption Costs & $\$ 593$ & $\$ 84$ \\
\hline Present Value, Relamping and Lamp Cost & $\$ 7587$ & $\$ 5036$ \\
\hline Annual Value, Relamping and Lamp Cost & $\$ 510$ & $\$ 339$ \\
\hline Present Value, Total Life-Cycle Cost & $\$ 16,670$ & $\$ 12,124$ \\
\hline Annual Value, Total Life-Cycle Cost & $\$ 1121$ & $\$ 815$ \\
\hline \multicolumn{3}{|l|}{ Total Annual Emissions } \\
\hline $\mathrm{CO}_{2}$ & $1927 \mathrm{~kg}$ & $275 \mathrm{~kg}$ \\
\hline $\mathrm{SO}_{2}$ & $2.48 \mathrm{~kg}$ & $0.35 \mathrm{~kg}$ \\
\hline NOx & $2.13 \mathrm{~kg}$ & $0.30 \mathrm{~kg}$ \\
\hline \multicolumn{3}{|l|}{$\begin{array}{l}\text { Comparative PV Data over 20-Year Study } \\
\text { Period for 12W PAR38 LED Lamps vs. 90W } \\
\text { (79W) Halogen PAR38 Lamps }\end{array}$} \\
\hline Net Energy Savings from LED Lamping (PV) & Baseline & $\$ 7561$ \\
\hline Net Savings from LED Lamping (PV) & Baseline & $\$ 4545$ \\
\hline Savings-to-Investment Ratio & Baseline & 1.82 \\
\hline Adjusted Internal Rate of Return & Baseline & $6.12 \%$ \\
\hline Estimated Simple Payback Occurs in Year & Baseline & 9 \\
\hline
\end{tabular}

In this gallery space with 54 accent lights, the LED replacement lamp compares favorably against the 90W 130V PAR38 halogen lamp, but at the low energy cost of $\$ 0.06 / \mathrm{kWh}$ the higher initial cost is not recouped until year 9 of operation because of very low power rates in Eugene, the high cost of the LED replacement lamp, and relatively low labor costs for replacing the museum's accent lighting. The total present value (PV) energy savings are \$7561, and the total PV life-cycle cost savings are \$4545.

The energy savings plus the savings due to reduced relamping labor costs will pay back more quickly when LED replacement lamp costs decrease in the near future. For example, the same life-cycle cost comparison using half the lamp cost (\$54 per LED lamp) will show a simple payback in year 4.

Similarly, if the lamp cost were to remain fixed at $\$ 108$ but the melded electric rate rose to the national average of $\$ 0.10 / \mathrm{kWh}$, the simple payback of the LED lamp compared to the halogen lamp would shorten to occur in year 6 . Or, at $\$ 0.15 / \mathrm{kWh}$, the simple payback would occur in year 4 . 
There are many factors to take into account in determining whether an LED system is cost-effective for a given site. This report focuses only on the initial investment, energy, and maintenance costs. In general, where their initial cost premium remains high, LED lighting systems can be cost-effective when electric utility rates are higher than average, hours of operation are long, and labor costs for relamping are high, none of which are the case in this museum gallery. Other factors could affect the calculation of value and payback, such as embedded energy cost or the cost of lamp disposal and increased waste. At this point, these factors are difficult to quantify, and they will vary according to location, so GATEWAY has not included them.

\subsection{Comments from the Museum Staff and Artist}

The museum staff, lighting designer, and artist all reported being pleased with the visual results in the Barker Gallery, including the color quality of the lamps. They commented that the LED lamps produced a better balance of color rendering across the color spectrum than the halogen system to which they were accustomed. (The halogen lamps tend to shortchange the blues and purples, but enhance the deep reds.)

Chris Jordan, artist, was gratified that there was no metameric ${ }^{4}$ shift in colors of his art, unlike that occurring with halogen lamps. His prints are color balanced for a daylight spectrum, so he prefers the LED spectrum, which has a somewhat higher blue content. The "living room" atmosphere created by the spot lighting of the Barker Gallery also worked very well, making his art more dramatic in appearance because of high contrast ratios between each piece and the surrounding areas. The artist commented that he also likes to see his art under an alternative lighting environment- “a blast” of higher color correlated temperature (CCT) floodlighting that is closer to daylighting than halogen provides.

\subsection{Gallery Test of Four Lamp Types}

The museum staff was interested in seeing the different LED PAR38 replacement lamp products compared side-by-side with the halogen lamp normally used for gallery lighting. The Gordon Gilkey Study Center Gallery, located on the first floor, below the Barker Gallery, was a convenient place to mount four clusters of similar artwork and illuminate each cluster with a different lamp. Each lamp was cataloged as delivering a beam spread of $20^{\circ}$ to $25^{\circ}$. The features of the four lamps are documented in Table 3. Each lamp was mounted in the museum's standard cylinder-shaped track head, and the face of the lamp was regressed sufficiently such that observers would have difficulty differentiating among the different lamp types by looking directly at them. (The regression of the lamp was not sufficient to affect its normal light distribution.) Lamps were mounted on a track parallel to the artwork wall, located at the same distance from the wall. All other lighting in the room was switched off and the test lamps were spaced far enough apart that each lamp’s light was isolated and viewed separately from the others.

\footnotetext{
${ }^{4}$ Metameric - relating to colors of different spectral composition that appear identical to the eye of a single observer under some lighting conditions but different under others. (Adapted from Merriam-Webster definition.)
} 
Table 3. Comparison of four lamps used in side-by-side test of PAR38 display lamps in Gilkey Gallery. Center beam candlepower, beam angle, lumens, watts, CCT, and CRI were taken from independent photometric tests performed for this GATEWAY study for lamps C and D. Data for A and B were derived from manufacturer’s data. Polar plot was approximated for lamp A.

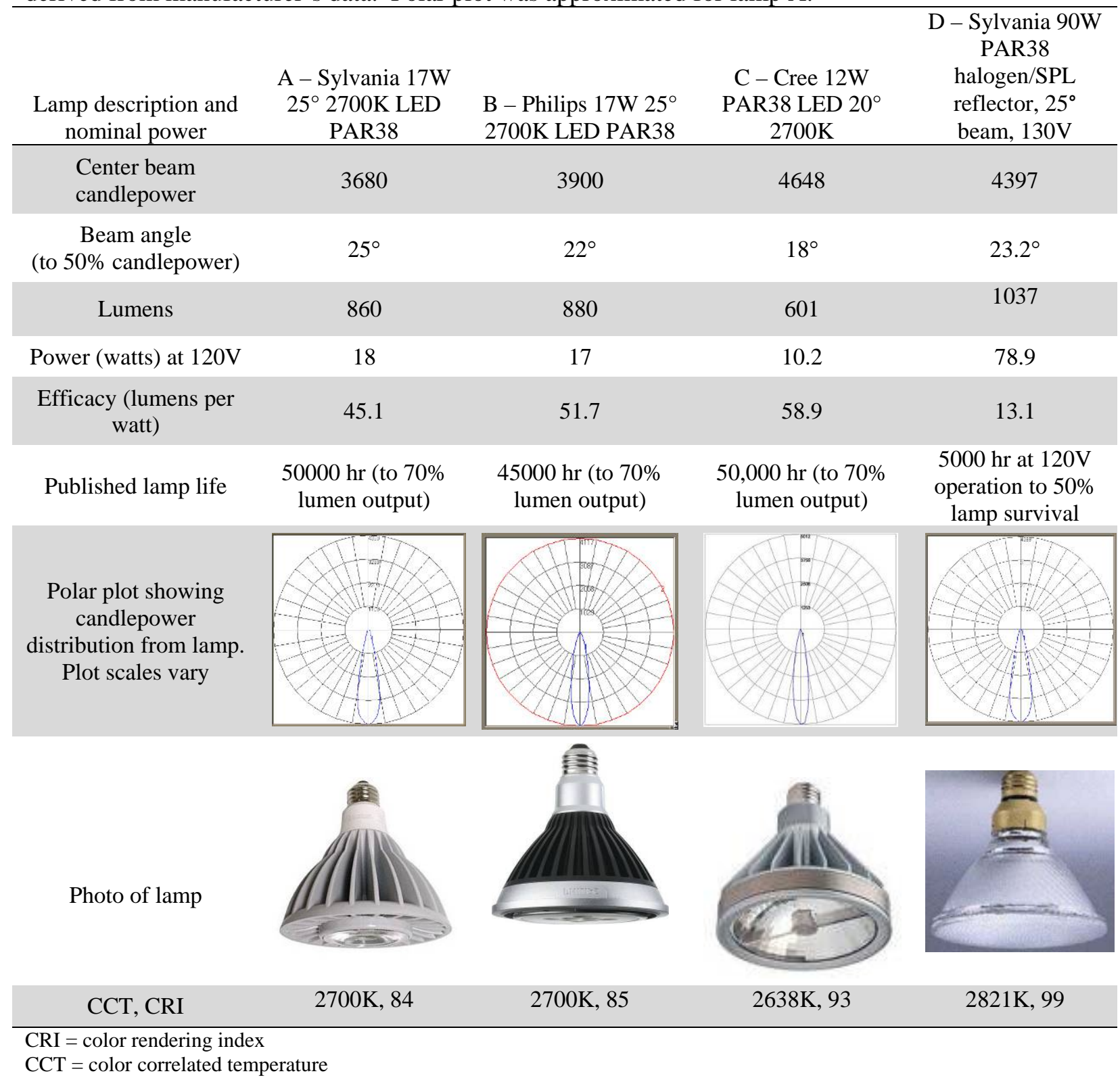

The museum provided four oil paintings on canvas with similar compositions and color palette, four black-and-white photographic prints of similar quality and size, and four MacBeth-Gretag color charts. One of each was mounted in a cluster on the wall and labeled A, B, C, or D from left to right. See Figure 10 and Figure 11. 


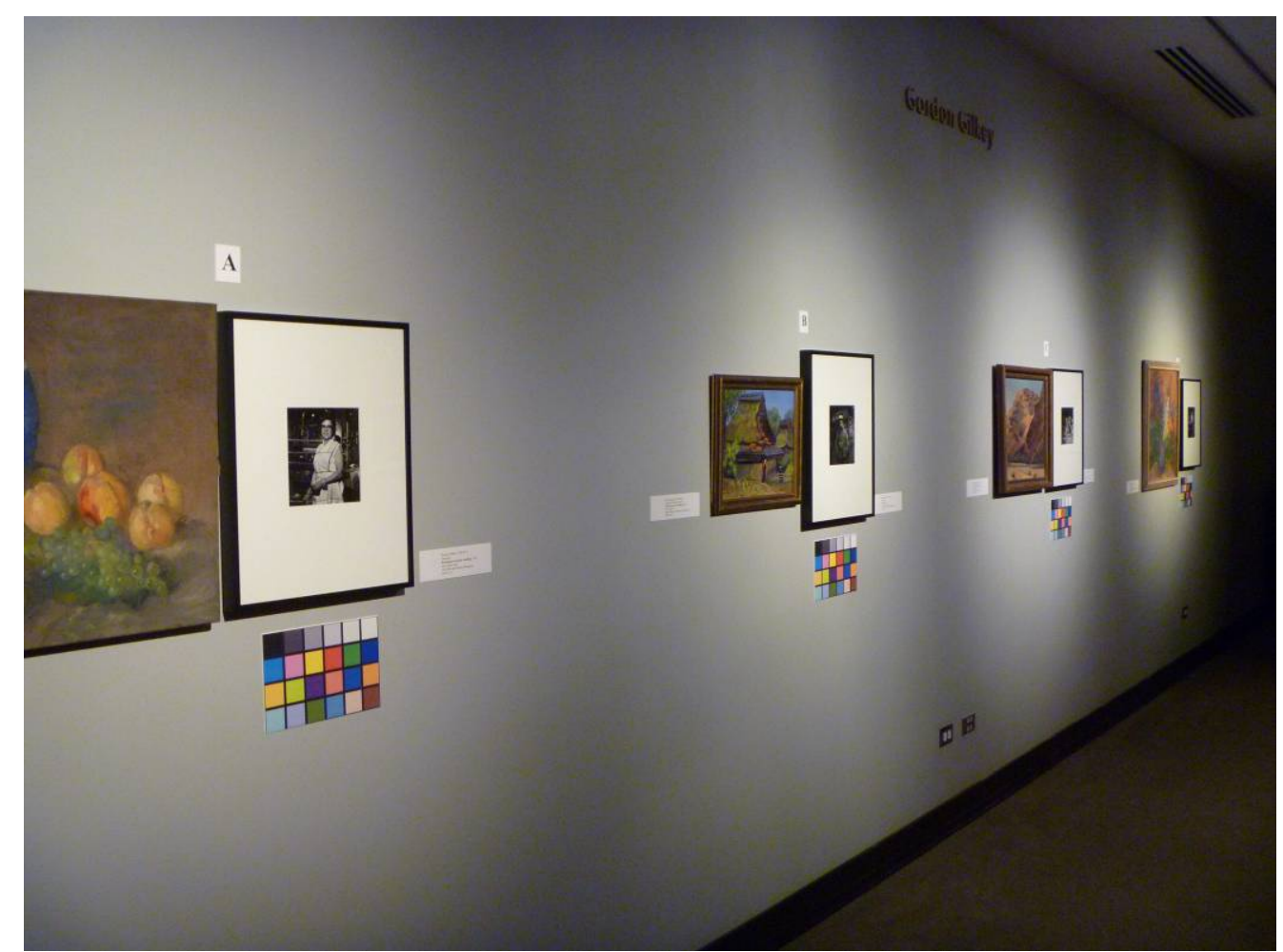

Figure 10. Gilkey Gallery with the four clusters of artwork arrayed along one wall. Each cluster was lighted with a different PAR38 lamp, lamp A (on left) through to lamp D (on far right). (Photo by PNNL.)

Figure 11 shows a single artwork cluster, lighted by lamp A, as viewed for the questionnaire. All four clusters of art were lighted from the same angle from a track head mounted at identical distances.

Vertical illuminances measured on the oil paintings and black-and-white photographs were as follows:

- A - 200 lx (19 fc) / 200 lx (19 fc )

- B - 260 lx (24 fc) / 260 lx (24 fc)

- C - 330 lx (31 fc) / 320 lx (30 fc)

- $\mathrm{D}-290 \mathrm{~lx}(27 \mathrm{fc}) / 280 \mathrm{~lx}(26 \mathrm{fc})$ 


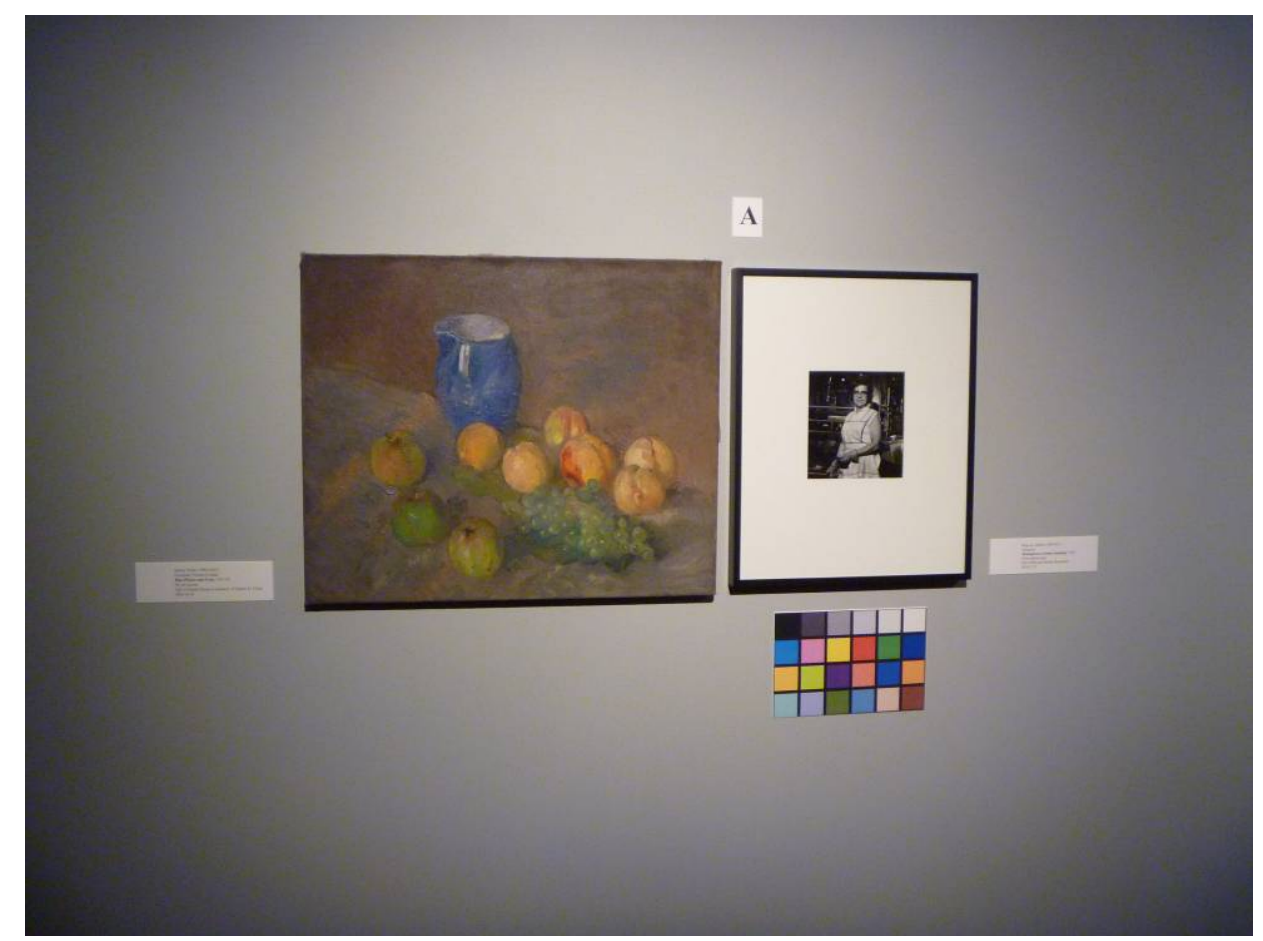

Figure 11. Cluster of artwork lighted by lamp A, as viewed for questionnaire. (Photo by PNNL.)

The questionnaire can be found in Appendix D. Four museum staff, including the curator, the lighting designer, and the director, completed the questionnaire, as did the artist. The results of these five questionnaires were analyzed together, separately from those of the visitors. It was assumed that these five individuals have many years of visual evaluation experience, and therefore they may be more critical and appreciative of colors and the range of subtle grey tones inherent in black-and-white photography than the general public.

Figure 12 shows the average questionnaire responses from the two groups. Fifty-nine visitors responded to the questionnaire. None knew which track heads used LED or halogen technology. Many respondents only answered some of the questions, so the averages in the table are based on the number of responses received for that question. 


\begin{tabular}{|c|c|c|c|c|c|c|c|c|c|c|c|c|}
\hline \multirow[t]{2}{*}{ Question No. } & \multicolumn{4}{|c|}{1} & \multicolumn{4}{|c|}{2} & \multicolumn{4}{|c|}{3} \\
\hline & \multicolumn{4}{|c|}{$\begin{array}{l}\text { The pattern of light (smoothness or } \\
\text { unevenness) on the art is: } \\
\text { 1=Unacceptable; } 2=\text { Poor; 3=Fair; } \\
\text { 4=Good; 5=Excellent }\end{array}$} & \multicolumn{4}{|c|}{$\begin{array}{l}\text { The lighting on the art is: } \\
\text { 1=Too Cool; 2=Somewhat Cool; 3=Just } \\
\text { Right; 4=Somwhat Warm; 5=Too Warm }\end{array}$} & \multicolumn{4}{|c|}{$\begin{array}{l}\text { The light's ability to render the artwork } \\
\text { colors accurately is: } \\
\text { 1=Unacceptable; } 2=\text { Poor; } 3=\text { Fair, } \\
\text { 4=Good; } 5=\text { Excellent }\end{array}$} \\
\hline Lamp & A & B & $\mathbf{C}$ & D & A & B & $\mathbf{C}$ & D & A & B & C & D \\
\hline & \multicolumn{4}{|c|}{ Highest is preferred } & \multicolumn{4}{|c|}{3 is preferred (neutral) } & \multicolumn{4}{|c|}{ Highest is preferred } \\
\hline $\begin{array}{c}\text { Average } \\
\text { Responses } \\
\text { from Museum } \\
\text { Staff, } \\
\text { including } \\
\text { Artist }[n=5]\end{array}$ & 3.8 & 4.4 & 4.8 & 3.4 & 3.2 & 3.0 & 3.6 & 2.6 & 3.8 & 4.2 & 4.4 & 3.0 \\
\hline $\begin{array}{c}\text { Average } \\
\text { Responses } \\
\text { from Visitors } \\
\text { (avg. score of } \\
\text { those } \\
\text { responding to } \\
\text { question) } \\
\text { [n=59 } \\
\text { maximum] }\end{array}$ & 3.4 & 3.6 & 3.4 & 3.6 & 3.1 & 2.6 & 4.0 & 2.3 & 3.2 & 3.9 & 3.3 & 2.9 \\
\hline
\end{tabular}

\begin{tabular}{|c|c|c|c|c|c|c|c|c|c|c|c|c|}
\hline \multirow[t]{2}{*}{ Question No. } & \multicolumn{4}{|c|}{4} & \multicolumn{4}{|c|}{5} & \multicolumn{4}{|c|}{6} \\
\hline & \multicolumn{4}{|c|}{$\begin{array}{l}\text { The lighting on the artwork helps me } \\
\text { see the artwork more clearly: } 1=\text { =Strongly } \\
\text { Agree; } 2=\text { Agree; } 3=\text { Neutral; } 4=\text { Disagree; } \\
\text { 5=Strongly Disagree }\end{array}$} & \multicolumn{4}{|c|}{$\begin{array}{l}\text { The suitability of the lighting system for } \\
\text { this color painting is: } \\
\text { 1=Excellent; } 2=\text { Good; } 3=\text { Adequate; } \\
\text { 4=Poor; } 5=\text { Unacceptable }\end{array}$} & \multicolumn{4}{|c|}{$\begin{array}{l}\text { The suitability of the lighting system for } \\
\text { this photographic print is: } \\
\text { 1=Excellent; } 2=\text { Good; } 3=\text { Adequate; } \\
\text { 4=Poor; } 5=\text { Unacceptable }\end{array}$} \\
\hline Lamp & A & B & C & D & $\mathbf{A}$ & B & C & D & $\mathbf{A}$ & B & C & D \\
\hline & \multicolumn{4}{|c|}{ Lowest is preferred } & \multicolumn{4}{|c|}{ Lowest is preferred } & \multicolumn{4}{|c|}{ Lowest is preferred } \\
\hline $\begin{array}{c}\text { Average } \\
\text { Responses } \\
\text { from Museum } \\
\text { Staff, } \\
\text { including } \\
\text { Artist [n=5] }\end{array}$ & 1.6 & 1.8 & 1.0 & 2.2 & 2.0 & 2.0 & 1.4 & 2.6 & 2.2 & 2.0 & 1.2 & 2.4 \\
\hline $\begin{array}{c}\text { Average } \\
\text { Responses } \\
\text { from Visitors } \\
\text { (avg. score of } \\
\text { those } \\
\text { responding to } \\
\text { question) } \\
\text { [n=59 } \\
\text { maximum] }\end{array}$ & 3.0 & 2.2 & 2.6 & 3.1 & 3.0 & 2.4 & 2.7 & 3.0 & 2.8 & 2.1 & 2.8 & 3.4 \\
\hline
\end{tabular}

Figure 12. Average responses on questionnaire from museum staff and exhibition artist, and visitors. Yellow indicates preferred lamp for each group.

Even though the museum staff and the artist were unaware of the installed lamp types, they preferred lamp C, which is the LED product they had earlier opted to use for the full gallery exhibition. Visitors preferred a different LED lamp (lamp B). One possible explanation for the different preferences is that the museum professionals are accustomed to conducting critical observation of art under halogen lighting, and may have seen the Cree LED PAR38 lamp as providing a very warm color of light very similar to that of the halogen lamp, but with augmentation of the blue colors. The general public may have not expected or appreciated the warm color of light to the same degree. An interesting and unexpected result from the questionnaire was that neither the staff nor the visitors consistently preferred the halogen lamp. 


\subsection{Conclusions}

This demonstration showed that carefully chosen LED replacement lamps can provide an equivalent or even preferred appearance of art in comparison to halogen lamps, while using only a fraction (14\% in this case) of the latter's energy use. Energy savings are significant and even with the museum's very low electric rates of \$0.06/kWh, only 2500 annual operating hours, and a high LED lamp cost of \$108 each, the LED replacement lamps are calculated to deliver a simple payback in year 9. Both the artist and the museum staff, who are expected to have high standards for visibility and color rendering of artistic details, had high praise for this technology and are looking forward to testing it on future exhibits.

\subsection{Lessons Learned}

\section{See the LED lamps in application before you buy them}

In this gallery, several LED lamps were tested for apparent color (CCT), color rendering, beam quality and size, and color consistency from lamp to lamp. Several of the LED PAR38 replacement lamps from other manufacturers tested poorly and were not selected. All of the lamps had similar color and beam specifications, but looked very different installed. This is a critical step in selecting LED replacement lamps for critical seeing applications.

\section{CRI may not correspond to preferred color rendering}

A test of four PAR38 lamp types illuminating clusters of art showed that the rank order of preference of lamps for color rendering did not correspond to the rank ordering of lamp CRI. A new or modified color rendering metric is needed for lighting designers and engineers, but in the meantime the designer should see the lamp in person and evaluate its color rendering of objects similar to the exhibit objects.

\section{Energy savings alone do not guarantee a rapid payback on LED replacement lamp investment}

Economic payback rates depend on several factors, including a significant power difference between the incumbent system and the replacement system. Although this museum gallery showed an $86 \%$ reduction in power, the simple payback doesn't occur until year 9 of operation because of the very low power rates in Eugene, the high cost of the LED replacement lamp, and the relatively low labor costs for replacing the museum's accent lighting. In general, payback times will be shorter when

- electric rates are higher (e.g., greater than the U.S. average $\$ 0.10 / \mathrm{kWh}$ melded rate),

- labor costs for relamping are high because of hard-to-reach locations, areas where skilled labor is costly, the need for access outside of normal work crew hours, access to the space is limited because of special security clearance, clean room requirements, etc., and

- hours of operation are extensive (e.g., longer than 40 hours per week).

Higher values in any one of these factors will shorten payback times and make the project more economically viable. 
If carefully chosen, LED replacement lamps can provide an equivalent or even preferred appearance of art

Warm color white LEDs are now available with a spectrum that allows a wide palette of colors (including shades of gray) to appear accurate and attractive. In critical seeing applications, such as exhibit lighting in some museums, LED replacement lamps are a viable, energy-efficient, long-life option. 
Appendix A: University of Oregon Jordan Schnitzer Museum of Art - Barker Gallery Input Data for Life-Cycle Cost Analysis

JSMA Barker Gallery Lighting - Input values for Life Cycle Cost Analysis

\begin{tabular}{|c|c|c|c|c|c|c|c|c|c|c|c|c|c|c|}
\hline \multicolumn{15}{|c|}{ Incumbent halogen Lamping, LED Lamping } \\
\hline$\stackrel{\coprod}{\stackrel{\Xi}{\alpha}}$ & $\begin{array}{l}\text { चे } \\
\text { हे } \\
\text { छ్ }\end{array}$ & 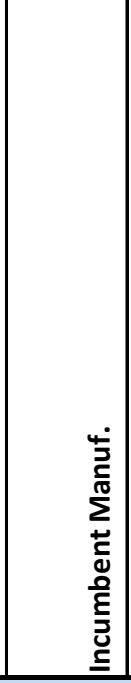 & हे & 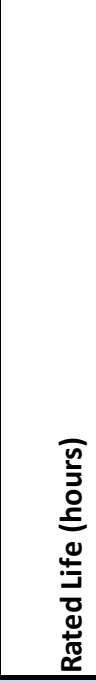 & $\stackrel{0}{0}_{3}^{0}$ & 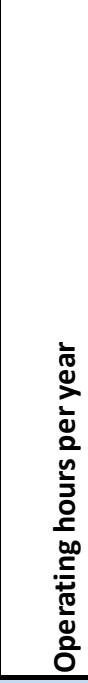 & 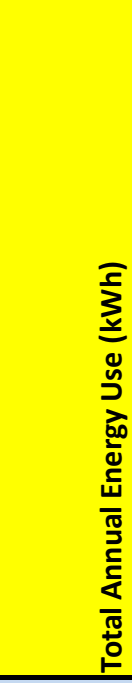 & 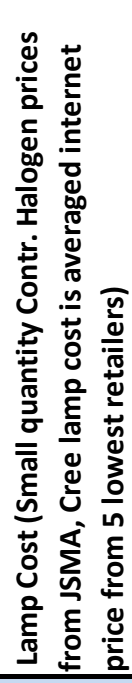 & 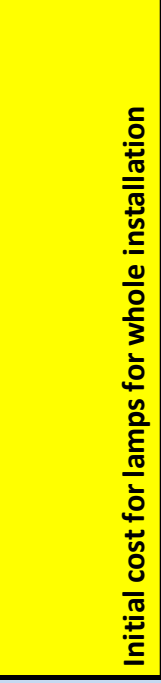 & 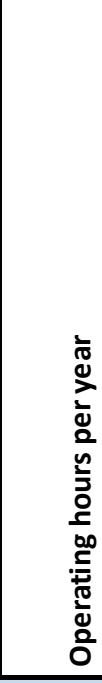 & 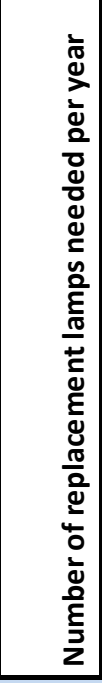 & 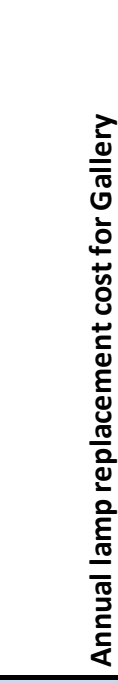 & 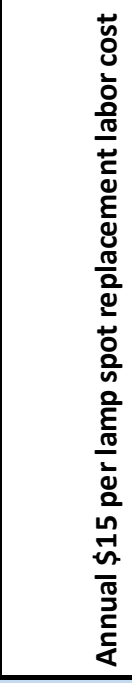 & 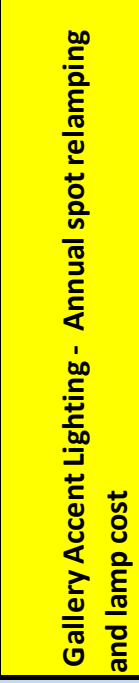 \\
\hline \multicolumn{15}{|l|}{ Lobby } \\
\hline Accent Lighting Incumbent Halogen & 49 & Sylvania & $\begin{array}{l}\text { 90PAR38/NFL25 } \\
\text { SPL reflector, } \\
\text { 130V }\end{array}$ & 5000 & 78.9 & 2548 & 9850.82 & $\$ 5.42$ & $\$ 265.58$ & 2,548 & 24.97 & $\$ 135.34$ & $\$ 374.56$ & $\$ 509.90$ \\
\hline Accent Lighting (Cree LED lamp) & 54 & Cree & $\begin{array}{l}\text { PAR38 LED 12W } \\
\text { LRP38 2700K }\end{array}$ & 50000 & 10.2 & 2548 & 1403.44 & $\$ 108.00$ & $\$ 5,832.00$ & 2,548 & 2.75 & $\$ 297.20$ & $\$ 41.28$ & $\$ 338.48$ \\
\hline
\end{tabular}





\section{Appendix B: Summary Life-Cycle Cost Calculations}

BLCC Report

Page 1 of 2

\section{NIST BLCC 5.3-10: Summary LCC}

Consistent with Federal Life Cycle Cost Methodology and Procedures, 10 CFR, Part 436, Subpart A

\section{General Information}

\begin{tabular}{|c|c|}
\hline File Name: & $\begin{array}{r}\text { C: }: \text { Documents and Settings }(\text { Naomi Miller } \backslash \text { My Documents } \backslash \text { PNNL projects } \backslash \text { University of Oregon } \\
\text { Museum\JSMA BLCC input file.xml }\end{array}$ \\
\hline Date of Study: & Tue Jul 26 17:46:23 PDT 2011 \\
\hline Analysis Type: & FEMP Analysis, Energy Project \\
\hline Project Name: & JSMA Barker Gallery \\
\hline Project Location: & Oregon \\
\hline Analyst: & Naomi Miller \\
\hline Base Date: & January 1,2011 \\
\hline Service Date: & January 1,2011 \\
\hline Study Period: & 20 years 0 months (January 1, 2011 through December 31, 2030) \\
\hline Discount Rate: & $3 \%$ \\
\hline $\begin{array}{l}\text { Discounting } \\
\text { Convention: }\end{array}$ & End-of-Year \\
\hline
\end{tabular}

\section{Alternative: Cree LED Par38}

LCC Summary

$\begin{array}{lrr} & \text { Present Value } & \text { Annual Value } \\ \text { Initial Cost } & \$ 5,832 & \$ 392 \\ \text { Energy Consumption Costs } & \$ 1,256 & \$ 84 \\ \text { Energy Demand Costs } & \$ 0 & \$ 0 \\ \text { Energy Utility Rebates } & \$ 0 & \$ 0 \\ \text { Water Usage Costs } & \$ 0 & \$ 0 \\ \text { Water Disposal Costs } & \$ 0 & \$ 0 \\ \text { Annually Recurring OM\&R Costs } & \$ 5,036 & \$ 339 \\ \text { Non-Annually Recurring OM\&R Costs } & \$ 0 & \$ 0 \\ \text { Replacement Costs } & \$ 0 & \$ 0 \\ \text { Less Remaining Value } & \$ 0 & \$ 0 \\ & ----- & -\cdots \\ \text { Total Life-Cycle Cost } & \$ 12,124 & \$ 815\end{array}$

Alternative: Sylvania 130V 90W PAR38 SPL/NFL25

LCC Summary

Initial Cost

Present Value Annual Value

$\$ 266 \$ 18$

file://C: Documents and Settings $\backslash D 3 Y 335 \backslash$ My Documents $\backslash$ Gateway Demonstration Project... 7/29/2011 


$\begin{array}{lrr}\text { Energy Consumption Costs } & \$ 8,817 & \$ 593 \\ \text { Energy Demand Costs } & \$ 0 & \$ 0 \\ \text { Energy Utility Rebates } & \$ 0 & \$ 0 \\ \text { Water Usage Costs } & \$ 0 & \$ 0 \\ \text { Water Disposal Costs } & \$ 0 & \$ 0 \\ \text { Annually Recurring OM\&R Costs } & \$ 7,587 & \$ 510 \\ \text { Non-Annually Recurring OM\&R Costs } & \$ 0 & \$ 0 \\ \text { Replacement Costs } & \$ 0 & \$ 0 \\ \text { Less Remaining Value } & \$ 0 & \$ 0 \\ & -\ldots-\ldots-\cdots\end{array}$

file://C:\Documents and Settings \D3Y335\My Documents Gateway Demonstration Project... 7/29/2011 


\section{Appendix C: Comparative Analysis of Life-Cycle Cost}

BLCC Report

Page 1 of 3

NIST BLCC 5.3-10: Comparative Analysis

Consistent with Federal Life Cycle Cost Methodology and Procedures, 10 CFR, Part 436, Subpart A

Base Case: Sylvania 130V 90W PAR38 SPL/NFL25

Alternative: Cree LED Par38

General Information

File Name:

Date of Study:

Project Name:

Project Location:

Analysis Type:

Analyst:

Base Date:

Service Date:

Study Period:

Discount Rate:

Discounting

Convention:

\section{Comparison of Present-Value Costs}

PV Life-Cycle Cost

\begin{tabular}{|c|c|c|c|}
\hline & Base Case & Alternative & Savings from Alternative \\
\hline \multicolumn{4}{|l|}{ Initial Investment Costs: } \\
\hline Capital Requirements as of Base Date & $\$ 266$ & $\$ 5,832$ & $-\$ 5,566$ \\
\hline \multicolumn{4}{|l|}{ Future Costs: } \\
\hline Energy Consumption Costs & $\$ 8,817$ & $\$ 1,256$ & $\$ 7,561$ \\
\hline Energy Demand Charges & $\$ 0$ & $\$ 0$ & \$0 \\
\hline Energy Utility Rebates & $\$ 0$ & $\$ 0$ & $\$ 0$ \\
\hline Water Costs & $\$ 0$ & $\$ 0$ & $\$ 0$ \\
\hline Recurring and Non-Recurring OM\&R Costs & $\$ 7,587$ & $\$ 5,036$ & $\$ 2,550$ \\
\hline Capital Replacements & $\$ 0$ & $\$ 0$ & \$0 \\
\hline Residual Value at End of Study Period & $\$ 0$ & $\$ 0$ & $\$ 0$ \\
\hline Subtotal (for Future Cost Items) & $\$ 16,404$ & $\$ 6,292$ & $\$ 10,112$ \\
\hline Total PV Life-Cycle Cost & $\$ 16,670$ & $\$ 12,124$ & $\$ 4,545$ \\
\hline
\end{tabular}

Net Savings from Alternative Compared with Base Case 


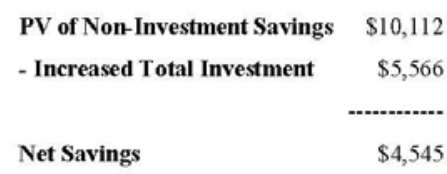

Savings-to-Investment Ratio (SIR)

$\mathbf{S I R}=1.82$

Adjusted Internal Rate of Return

AIRR $=6.12 \%$

Payback Period

Estimated Years to Payback (from beginning of Service Period)

Simple Payback occurs in year 9

Discounted Payback occurs in year 10

\section{Energy Savings Summary}

Energy Savings Summary (in stated units)

$\begin{array}{lcccc}\text { Energy } & \text {--Average } & \text { Annual } & \text { Consumption--- } & \text { Life-Cycle } \\ \text { Type } & \text { Base Case } & \text { Alternative } & \text { Savings } & \text { Savings } \\ \text { Electricity } & 9,850.8 \mathrm{kWh} & 1,403.4 \mathrm{kWh} & 8,447.4 \mathrm{kWh} & 168,924.5 \mathrm{kWh}\end{array}$

Energy Savings Summary (in MBtu)

$\begin{array}{lcccc}\text { Energy } & \text {--Average } & \text { Annual } & \text { Consumption--- } & \text { Life-Cycle } \\ \text { Type } & \text { Base Case } & \text { Alternative } & \text { Savings } & \text { Savings } \\ \text { Electricity } & 33.6 \mathrm{MBtu} & 4.8 \mathrm{MBtu} & 28.8 \mathrm{MBtu} & 576.4 \mathrm{MBtu}\end{array}$

\section{Emissions Reduction Summary}

\begin{tabular}{|c|c|c|c|c|}
\hline Energy & --Average & Annual & Emissions--- & Life-Cycle \\
\hline Type & Base Case & Alternative & Reduction & Reduction \\
\hline \multicolumn{5}{|c|}{ Electricity } \\
\hline $\mathrm{CO} 2$ & $1,926.75 \mathrm{~kg}$ & $274.50 \mathrm{~kg}$ & $1,652.25 \mathrm{~kg}$ & $33,040.47 \mathrm{~kg}$ \\
\hline $\mathrm{SO} 2$ & $2.48 \mathrm{~kg}$ & $0.35 \mathrm{~kg}$ & $2.13 \mathrm{~kg}$ & $42.57 \mathrm{~kg}$ \\
\hline NOx & $2.13 \mathrm{~kg}$ & $0.30 \mathrm{~kg}$ & $1.82 \mathrm{~kg}$ & $36.49 \mathrm{~kg}$ \\
\hline \multicolumn{5}{|l|}{ Total: } \\
\hline $\mathrm{CO} 2$ & $1,926.75 \mathrm{~kg}$ & $274.50 \mathrm{~kg}$ & $1,652.25 \mathrm{~kg}$ & $33,040.47 \mathrm{~kg}$ \\
\hline
\end{tabular}




$\begin{array}{lllll}\text { SO2 } & 2.48 \mathrm{~kg} & 0.35 \mathrm{~kg} & 2.13 \mathrm{~kg} & 42.57 \mathrm{~kg} \\ \text { NOx } & 2.13 \mathrm{~kg} & 0.30 \mathrm{~kg} & 1.82 \mathrm{~kg} & 36.49 \mathrm{~kg}\end{array}$





\section{Appendix D: Questionnaire on Lighting Mockup in Gilkey Gallery}

\section{Lighting Questionnaire for Jordan Schnitzer Museum of Art}

The U.S. Department of Energy (DOE), Eugene Water and Electric Board (EWEB), and Bonneville Power Administration (BPA) are collaborating with the Jordan Schnitzer Museum of Art at the University of Oregon to investigate saving energy with LED lighting. One aspect of the demonstration is a comparison of lighting quality among different lamp types.

We are interested in YOUR impressions of the lighting effects from four different light bulbs, some of which are energy-efficient and some of which are conventional bulbs. To maintain statistical objectivity we haven't identified which are which. Each type of lamp is illuminating one full-color painting and one black \& white photographic print.

Please look at the lighting on each artwork and tell us what you like or don't like, using the attached form. Your responses will be kept anonymous.

Your candid input will help us make energy-efficient lighting better; helping improve the lighting products that you'll be able to buy for your homes and workplaces in the near future.

Thank you for taking the time to help with this project! We will post the results on the Jordan Schnitzer Museum of Art website following the conclusion of this effort, and the results will also be incorporated into the GATEWAY final project report ultimately posted on the DOE Solid-State Lighting Program website (www.ssl.energy.gov/gatewaydemos.htm).
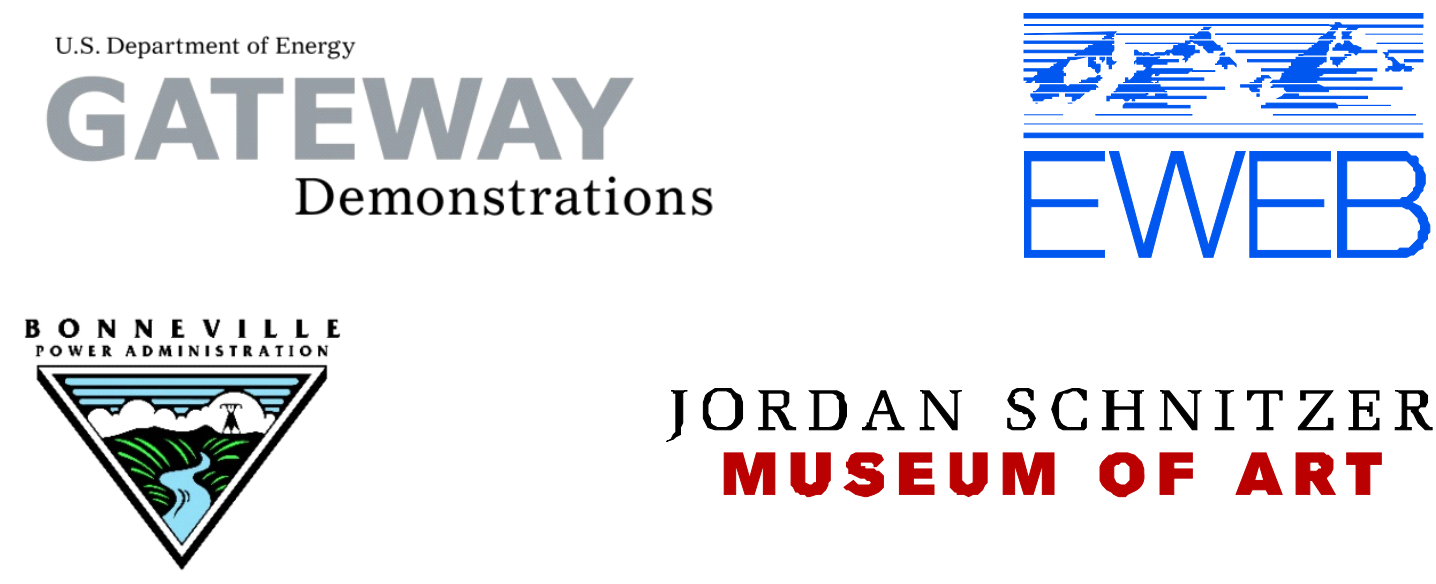

JORDAN SCHNITZER MUSEUM OF ART 


\section{Lighting Questionnaire for Jordan Schnitzer Museum of Art}

Your name (optional):

Title (optional):

Please circle the response that most closely matches your own opinion for each of the four groups of artwork. We are interested in your honest opinion, and there are no right or wrong answers.

1. The pattern of light (smoothness or unevenness) on the art is:

\begin{tabular}{|c|c|c|c|}
\hline A & B & C & D \\
\hline Unacceptable & Unacceptable & Unacceptable & Unacceptable \\
Poor & Poor & Poor & Poor \\
Fair & Fair & Fair & Fair \\
Good & Good & Good & Good \\
Excellent & Excellent & Excellent & Excellent \\
\hline
\end{tabular}

2. Look at the color appearance of the light on each set of artworks. "Cool” means bluish-white in color, and "Warm" means yellowish-white or reddish-white.

The lighting on the art is:

\begin{tabular}{|c|c|c|c|}
\hline A & B & $\mathrm{C}$ & $\mathrm{D}$ \\
\hline $\begin{array}{c}\text { Too cool } \\
\text { Somewhat cool } \\
\text { Just right } \\
\text { Somewhat warm } \\
\text { Too warm }\end{array}$ & $\begin{array}{c}\text { Too cool } \\
\text { Somewhat cool } \\
\text { Just right } \\
\text { Somewhat warm } \\
\text { Too warm }\end{array}$ & $\begin{array}{c}\text { Too cool } \\
\text { Somewhat cool } \\
\text { Just right } \\
\text { Somewhat warm } \\
\text { Too warm }\end{array}$ & $\begin{array}{c}\text { Too cool } \\
\text { Somewhat cool } \\
\text { Just right } \\
\text { Somewhat warm } \\
\text { Too warm }\end{array}$ \\
\hline
\end{tabular}

3. The light's ability to render the artwork colors accurately is:

\begin{tabular}{|c|c|c|c|}
\hline A & B & C & D \\
\hline Unacceptable & Unacceptable & Unacceptable & Unacceptable \\
Poor & Poor & Poor & Poor \\
Fair & Fair & Fair & Fair \\
Good & Good & Good & Good \\
Excellent & Excellent & Excellent & Excellent \\
Reason: & Reason: & Reason: & Reason: \\
\hline
\end{tabular}

(Reasons might include “richer reds”, "better blues”, etc.) 
4. The lighting on the artwork helps me see the artwork more clearly:

\begin{tabular}{|c|c|c|c|}
\hline A & B & C & D \\
\hline Strongly agree & Strongly agree & Strongly agree & Strongly agree \\
Agree & Agree & Agree & Agree \\
Neutral & Neutral & Neutral & Neutral \\
Disagree & Disagree & Disagree & Disagree \\
Strongly disagree & Strongly disagree & Strongly disagree & Strongly disagree \\
& & & \\
\hline
\end{tabular}

5. The suitability of the lighting system for this color painting is:

\begin{tabular}{|c|c|c|c|}
\hline A & B & C & D \\
\hline Excellent & Excellent & Excellent & Excellent \\
Good & Good & Good & Good \\
Adequate & Adequate & Adequate & Adequate \\
Poor & Poor & Poor & Poor \\
Unacceptable & Unacceptable & Unacceptable & Unacceptable \\
\hline
\end{tabular}

6. The suitability of the lighting system for this photographic print is:

\begin{tabular}{|c|c|c|c|}
\hline A & B & C & D \\
\hline Excellent & Excellent & Excellent & Excellent \\
Good & Good & Good & Good \\
Adequate & Adequate & Adequate & Adequate \\
Poor & Poor & Poor & Poor \\
Unacceptable & Unacceptable & Unacceptable & Unacceptable \\
\hline
\end{tabular}

7. Please provide any additional thoughts you have about the lighting:
A
B
C
$\mathrm{D}$

Overall 



\section{Distribution}

No. of

Copies

\# Name

Organization

Address

City, State and ZIP Code

\# Organization

Address

City, State and ZIP Code

Name

Name

Name

Name

Name (\#)

\# Name

Organization

Address

City, State and ZIP Code
No. of

\section{Copies}

\section{\# Foreign Distribution}

\# Name

Organization

Address

Address line 2

COUNTRY

\# Local Distribution

Pacific Northwest National Laboratory

Name

Name

Mailstop

Name

Name

Name
Mailstop

Mailstop

Mailstop

(PDF) 




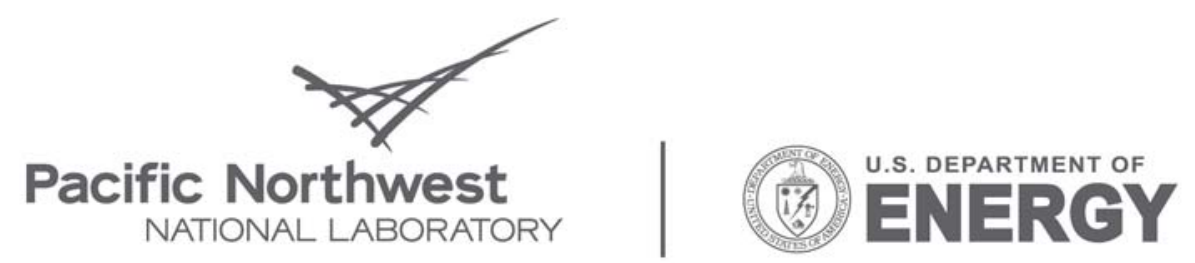

Proudly Operated by Battelle Since 1965

902 Battelle Boulevard

P.O. Box 999

Richland, WA 99352

1-888-375-PNNL (7665)

www.pnl.gov 